\title{
Virtual screening of acyclovir derivatives as potential antiviral agents: design, synthesis and biological evaluation of new acyclic nucleoside ProTides
}

\author{
Marco Derudas $^{+,}{ }^{*}$, Christophe Vanpouille ${ }^{++}$, Davide Carta $^{+}$, Sonia Zicari ${ }^{++}$, Graciela Andrei ${ }^{+}$ \\ ${ }^{++}$, Robert Snoeck ${ }^{++}$, Andrea Brancale ${ }^{+}$, Leonid Margolis ${ }^{++}$, Jan Balzarini ${ }^{+++}$, and \\ Christopher McGuigan ${ }^{+} \S$ \\ +Cardiff School of Pharmacy and Pharmaceutical Sciences, Cardiff University, Cardiff, CF10 3NB, \\ UK \\ ++Eunice Kennedy Shriver National Institute of Child Health and Human Development, National \\ Institutes of Health, Bethesda, MD 20892, USA \\ ${ }^{+++R e g a ~ I n s t i t u t e ~ f o r ~ M e d i c a l ~ R e s e a r c h, ~ K U ~ L e u v e n, ~ B-3000 ~ L e u v e n, ~ B e l g i u m ~}$
}

\begin{abstract}
Following our findings on the anti-HIV activity of acyclovir phosphate prodrugs, we herein report the ProTide approach applied to a series of acyclic nucleosides aimed at the identification of novel and selective antiviral (i.e. HIV) agents. Acyclic nucleoside analogues used in this study were identified through a virtual screening using adenylate/guanylate kinase, HIV RT, and human DNA polymerase. A total of thirty-nine new phosphate prodrugs were synthesised and evaluated against HIV-1 (in in vitro and in ex-vivo human tonsillar tissue system) and human herpesviruses. Several ProTide compounds showed good potency (low micromolar range) against HIV-1 while the parent nucleosides were not effective. Also, pronounced inhibition of herpesvirus replication was observed. A carboxypeptidase-mediated hydrolysis study was performed for the selection of compounds showing different metabolic patterns.
\end{abstract}

\section{Introduction}

Human immunodeficiency virus (HIV) infection currently affects over 36 million people worldwide and caused about 35 million deaths. ${ }^{1}$ The rate of new HIV infections is still increasing, especially in third-world countries. ${ }^{1}$ Twenty-six anti-HIV drugs are currently available and they act by interacting with different targets essential for the viral replication, such as reverse transcriptase (RT), protease, integrase, or the fusion/entry step. ${ }^{2}$ The current antiretroviral therapy significantly improved the life expectation of HIV-infected individuals by reducing the viral load and postponing the insurgence of AIDS. Despite their success these drugs carry some limitations, such as the onset of drug resistance and adverse side-

*Correspondence to: Dr Marco Derudas, Cardiff School of Pharmacy and Pharmaceutical Sciences, Cardiff University, Cardiff, CF10 3NB, UK, Phone: +44 (0) 1273876591, m.derudas@sussex.ac.uk.

$\S$ This work is dedicated to the memory of Prof. Chris McGuigan, a great colleague and scientist, invaluable source of inspiration and love for research 
effects. Whilst the first issue has been addressed using a cocktail of different antiretroviral drugs, the second one is still present and plays a huge impact in the patients' compliance.

In this regard, our therapeutic effort prompted us to the discovery of acyclovir (ACV), a gold-standard drug for herpes simplex virus (HSV) and varicella zoster virus (VZV) infections, as a new potential anti-HIV agent. It was noted that ACV inhibited HIV in the presence of human herpesviruses (HHV) and this activity was attributed to the conversion of ACV to its monophosphate form by the HHV-encoded kinases; further phosphorylation steps provided the active triphosphate form of ACV able to inhibit HIV-RT. ${ }^{3}$

To circumvent the required first phosphorylation step of ACV, a series of phosphate prodrugs, so called ProTides, were synthesised. These compounds showed anti-HIV activity in the absence of HHV infection, demonstrating their nucleoside kinase independence. ${ }^{4,5}$ These findings were also supported in a different study, where ACV phosphate prodrugs showed a full retention of antiviral activity against HSV-1 and VZV thymidine kinase (TK)deficient strains. ${ }^{6}$ Unfortunately, these compounds proved to be somewhat cytotoxic in some assays. ${ }^{4}$ To overcome this issue and to better understand the full potential of acyclic nucleoside analogues as new anti-HIV agent, we performed a virtual screening on a library of ACV derivatives. We then synthesised and biologically evaluated a series of different acyclic nucleosides and their corresponding ProTides and investigated their mechanism of bioactivation using a well-established enzymatic method.

\section{Molecular modelling: virtual screening}

The objective of this study was to increase the specificity of the compounds for HIV-1 RT and reduce the affinity for the cellular DNA polymerase, while still retaining substrate action for adenylate and guanylate kinases. A virtual screening using docking techniques was performed on HIV-1 RT, adenylate or guanylate kinase, and a model of DNA polymerase $\gamma$. The docking using nucleoside kinases involved in the first step of drug phosphorylation were not considered since the phosphoramidate ProTide approach will be applied to the selected compounds.

Firstly, a database of 3600 compounds was built considering modifications at the base and at the acyclic sugar moieties (Figure 1), including: simple and branched acyclic sugars (brown); oxygen, methylene or sulphur at the 2'-position (yellow); substitution at the C-8position of the base including: hydrogen, methyl, fluorine, bromine or chlorine (red); substitution at the C-7-position of the base including: nitrogen or carbon (hydrogen or methyl substituted) (blue); substitution at the C-6-position of the base including: carbonyl, amine, chlorine, methoxide, ethoxide, phenoxy, methylamine, or cyclopropylamine (magenta); substitution at the 2-NH position of the base including: hydrogen, methyl, ethyl, phenyl or benzyl (green).

Based on the modification at the 6-position of the nucleobase, the database was divided in two groups: 6-carbonyl derivatives (450 compounds), which showed base-pairing with cytidine; and 6-O-modified and 6-N-modified derivatives (3150 compounds) which showed better base pairing with thymidine (Figure 2). 
The first screening was performed on HIV-RT using a crystal structure of the enzyme cocrystallised with tenofovir diphosphate (PDB: 1T05). ${ }^{7}$ The original structure was used for the 6-modified ACV derivatives, while the substitution of a thymine by a cytidine was necessary for the 6-carbonyl derivatives. All the compounds were docked in their triphosphate form and the stereochemistry, when present, was considered. For this screening, a root mean square deviation (RMSD) $<1 \AA$ between the base of the compounds docked and the base of co-crystallised tenofovir diphosphate was considered leading to a total of 984 compounds. Interestingly, it was observed that branched sugar derivatives were welltolerated due to the presence of a pocket in the proximity of amino acid residues Tyr115 and Phe116, which allowed the accommodation of a substitution in the acyclic sugar moiety. Moreover, the presence of a cleft that allows a potential substitution at the 2-amino position of the base was observed. In addition, substitutions at the 8-position of the base, especially with halogens, were well-tolerated.

Interestingly, the compound that showed the best interactions (RMSD $<0.18 \AA$ ) was ganciclovir (GCV)-TP (Figure 3), drug treatment of choice for human cytomegalovirus infections.

For the second screening human adenylate kinase (PDB: $2 \mathrm{C} 95)^{8}$ or mouse guanylate kinase (PDB: 1LVG, $88 \%$ human homology) ${ }^{9}$ were considered for the 6-modified and for the 6carbonyl analogues respectively.

For these docking experiments, two different RMSDs were considered: the first one regarding the position of the base $(<1 \AA)$ and the second one considering the position of the phosphate moiety $(<3 \AA$ ). These two values allowed a good position of the base and a reasonable position for the phosphate moiety, which, however, in some cases, was slightly moved compared to the crystallized compound.

Similar to the results obtained for the HIV-RT docking, branched sugar derivatives showed the best docking results in both series. In addition, the halogen substitution at the 8-position for the 6-carbonyl series was well-tolerated. This second screening led to a total of 218 compounds, with the 6-carbonyl derivatives being preferred over the 6-modified ones.

The last part of the virtual screening included the use of human DNA polymerases. It is known that the toxicity of nucleoside analogues, especially HIV-1 RT inhibitors, is usually due to interactions with these enzymes. ${ }^{10-13}$ The subtypes of human DNA polymerase mainly involved in the cytotoxicity are $a$ and $\gamma$, with the latter being able to incorporate antiviral nucleotide analogues, which then act as a DNA chain terminators and consequently show cytotoxicity. ${ }^{14-17}$

As the crystal structures for both human DNA polymerases have not yet been solved, a model for the human polymerase $\gamma$ that covers the polymerase active site with the highest degree of homology with T7 DNA polymerase ${ }^{18}$ has been used for the final step of our virtual screening.

In this case, the results were analysed visually, excluding all the compounds that showed good interactions with the catalytic site of the enzyme. A total of twenty-five compounds 
were identified, and amongst these, five compounds were selected which displayed the best scoring for all the three docking experiments and that were easily accessible from a synthetic point of view. A summary of the virtual screening is depicted in Figure 4.

Figure 5 shows the five compounds selected from the virtual screening, which are: ganciclovir (1), penciclovir (2), 2'-thio derivative of ganciclovir (3), 6-chloropenciclovir (4), and 6-methoxypenciclovir (5).

\section{Chemistry}

The desired phosphoramidates were synthesised using a widely procedure based on the use of tert-butylmagnesium chloride $\left({ }^{\mathrm{t}} \mathrm{BuMgCl}\right)$ as reported by Uchiyama. ${ }^{19}$

The desired phosphorochloridates were prepared according to our established method by coupling the appropriate aryl dichlorophosphate with the appropriate amino acid ester to yield the desired compound as an oil. ${ }^{4}$

\section{Synthesis of ganciclovir 1 ProTides}

For the synthesis of ganciclovir 1 ProTides (Scheme 1), the 2-amino functionality of the guanine base was protected using $\mathrm{N}, \mathrm{N}$-dimethylamino formamide according to the literature. ${ }^{4}$ The coupling with the appropriate phosphorochloridate (2-8 eq) was performed using an excess of ${ }^{\mathrm{t}} \mathrm{BuMgCl}(2-3 \mathrm{~mol} / \mathrm{eq})$ in a mixture of THF and pyridine. The presence of the extra hydroxyl group in the molecule played a crucial role in the synthesis of the desired compounds resulting in some cases only in the isolation of the bisphosphate prodrug ( 9 and 10). The dimethylformamidine group was removed by refluxing in 2-propanol for $24-80 \mathrm{~h}$ yielding the desired compounds 15-22.

To overcome the issue related to the bis-phosphorylated side-product, the monomethoxytrityl (MMT) of $\mathbf{1}$ was synthetized using monomethoxytrityl chloride (2.2 eq), triethylamine (3 eq) and DMAP (cat.) in DMF. The reaction held two different products: $\mathbf{2 3}$ bearing two protecting groups at the 2-amino position and at the 3'-hydroxyl position and $\mathbf{2 4}$ bearing the monomethoxytrityl group only at the 2 -amino position.

Compound 23 was then reacted with phenyl(benzoxy-L-alaninyl)-phosphorochloridate (2 eq) in the presence of ${ }^{\mathrm{t}} \mathrm{BuMgCl}$ ( 2 eq) to yield the desired compound $\mathbf{2 5}$; compound $\mathbf{2 4}$ was reacted with 1-naphthyl(benzoxy-L-alaninyl)-derivative under the same condition giving the desired mono-phosphorylated derivative $\mathbf{2 6}$. The deprotection of the monomethoxytrityl group was performed using an excess of para-toluene sulfonic acid in DCM/MeOH (7/3) yielding the desired compounds $\mathbf{2 7}$ and $\mathbf{2 8}$.

\section{Synthesis of penciclovir 2 ProTides}

The same synthetic approach was applied for the synthesis of compound 2 ProTides. Initially, the 2-amino functionality of the guanine base was protected under the same conditions seen previously to give compound 29 in excellent yield. Unfortunately, the coupling with the appropriate phosphorochloridate resulted in the isolation of only the bisphosphorylated compounds $\mathbf{3 0}$ and $\mathbf{3 1}$ for L-alaninyl derivatives; while both bis- (32 and $\mathbf{3 4}$ ) 
and mono-phosphorylated (33 and $\mathbf{3 5}$ ) derivatives were obtained when dimethylglycine phosphorochloridates were used. The protecting group was removed by refluxing in 2propanol to give the final compounds (36-41) in low yield due to degradation of the products.

To overcome the issue related to the deprotection step, $\mathbf{2}$ was directly reacted with phenyl(benzoxy-L-alaninyl)-phosphorochloridate yielding compound $\mathbf{4 2}$ in very low yield (5\%). Alternatively, compound $\mathbf{2}$ was converted to the bis-MMT derivative $\mathbf{4 3}$ and subsequently reacted with the appropriate phosphorochloridate to give $\mathbf{4 4}$. The deprotection step was carried out using para-toluene sulfonic acid affording the desired compound $\mathbf{4 5}$.

The protection of both $\mathbf{1}$ and $\mathbf{2}$ with the para-methoxytrityl group proved to be an effective approach for the synthesis of monophosphorylated derivatives, having a milder deprotection step, which led to a higher overall yield.

\section{Synthesis of compound 3 and its ProTides}

The synthesis of $\mathbf{3}$ was performed adapting a reported procedure. ${ }^{20}$ Compound $\mathbf{4 6}$, easily made by reacting epichlorohydrin with benzyl alcohol in the presence of sodium hydride and tetra-n-butyl ammonium iodide, was reacted with tosyl chloride to give derivative $\mathbf{4 7}$, which was then converted into its thio-acetyl derivative $\mathbf{4 8}$ by heating with potassium thioacetate in anhydrous DMF. The deprotection of the acetyl group was performed either in methanolic ammonia or using sodium methoxide in methanol affording compound $\mathbf{4 9}$ in comparable yield. A three-steps coupling reaction between diacetyl-guanine and $\mathbf{4 8}$ gave the desired compound 50; the N-7 isomer was also isolated during the purification step. The benzyl protecting groups were then converted into acetyl groups, using acetic anhydride and $\mathrm{BF}_{3} \cdot \mathrm{OEt}_{2}$ to yield $\mathbf{5 1}$, which was then fully deprotected using methanolic ammonia to obtain the desired compound $\mathbf{3}$.

Compound $\mathbf{3}$ was protected with N,N-dimethylformamide to give $\mathbf{5 2}$ in $88 \%$ yield followed by the coupling with the appropriate phosphorochloridate affording only the bisphosphorylated derivatives $\mathbf{5 3}$ and $\mathbf{5 4}$. The deprotection was only successful for compound 53 leading the desired compound $\mathbf{5 5}$; whilst in the case of $\mathbf{5 4}$, degradation of the starting material was observed (Scheme 6).

\section{Synthesis of nucleosides analogues 4 and 5, and their ProTides}

Compounds 4 and $\mathbf{5}$ were prepared according to a procedure reported by Toori et al. ${ }^{21}$

(Scheme 7). Compound 2 was acetylated using acetic anhydride and DMAP (cat.) to obtain 57 in good yield (84\%). Chlorination at the 6-position was achieved using $\mathrm{POCl}_{3}$ in the presence of benzyltriethylammonium chloride and N,N-dimethylaniline to yield $\mathbf{5 8}(67 \%)$. The deprotection of the acetyl group using methanolic ammonia at room temperature led only to the deprotection of the acetyl group, giving compound 4 (85\%); while the use of sodium methoxide in methanol at $40{ }^{\circ} \mathrm{C}$ afforded compound $\mathbf{5}(71 \%)$.

Compounds $\mathbf{4}$ and $\mathbf{5}$ were coupled with the appropriate phosphorochloridate under the same conditions described above. The presence of the 6-chloro or 6-methoxy group greatly 
improved their solubility compared to the previous analogues with the subsequent improvement of their reactivity.

In the case of 4, the monophosphorylated derivative $\mathbf{5 9}$ and the bisphosphorylated $\mathbf{6 0}$ were obtained in $9 \%$ and $24 \%$ yield respectively (Scheme 8 ).

In the case of compound $\mathbf{5}$, given the previous success of 6-methoxy purine analogues in another antiviral program, ${ }^{22}$ a wider range of ProTides was considered (Scheme 9). Most of the time, monophosphorylated derivatives (66-72) were obtained together with the bisphosphorylated ProTides (61-65).

The monophosphorylated ProTides of all the parent nucleosides considered were obtained as an inseparable mixture of isomers due to the formation of a new chiral centre at the acyclic sugar side-chain.

To overcome this issue, the cyclic ProTides derivatives of $\mathbf{2}$ and $\mathbf{4}$ were prepared. Compound 6 was reacted with ethoxy-L-alaninyl dichlorophosphate using ${ }^{t} \mathrm{BuMgCl}$ in $\mathrm{THF} / \mathrm{pyridine}$ yielding compound $\mathbf{7 3}$ followed by deprotection in 2-propanol to afford compound $\mathbf{7 4}$ (Scheme 10).

Similarly, $\mathbf{4}$ was directly coupled with benzoxy-L-alaninyl phosphorochloridate providing the desired compound 75 (Scheme 11).

In an attempt to identify the formation of a metabolite in an enzymatic assay which will be discussed later, the monoacetylated derivative of $\mathbf{7 6}$ and its ProTide $\mathbf{7 7}$ were synthesised (Scheme 12).

Treating 58 with ammonia gas generated in situ at $0{ }^{\circ} \mathrm{C}$ gave the desired compound 76 in moderate yield. The synthesis of ProTide $\mathbf{7 7}$ was then performed using a standard procedure obtaining the desired compound as a mixture of four diasteroisomers, as clearly depicted in the corresponding ${ }^{31} \mathrm{P}-\mathrm{NMR}$ spectra.

\section{Biological Results}

\section{Anti-HIV activity}

The synthesised compounds were first tested for HIV-1 and HIV-2 inhibition in MT- 4 cell cultures (Table 1). While the parent nucleosides 1-5 were inactive against HIV-1, several of the ProTides showed anti-HIV activity, with the most potent being in the low $\mu \mathrm{M}$ range. Mono-ProTides $(\mathbf{1 6}, \mathbf{2 0}, \mathbf{2 2}, 27,28)$ of compound 1 showed anti-HIV activity between 8$>150 \mu \mathrm{M}$ but an antiproliferative effect in a range between $20->150 \mu \mathrm{M}$. In the case of bisProTides $(\mathbf{1 5}, \mathbf{1 7}, \mathbf{1 8}, \mathbf{1 9}$, and 21) the anti-HIV activity varied between 8.5 and $>150 \mu \mathrm{M}$ and the antiproliferative effect between 8 and $150 \mu \mathrm{M}$. However, for the most active ones (i.e. 15, 17,19 and 22) the antiviral activity can be related to the relatively high cytotoxicity observed for these compounds.

Penciclovir (2) mono-ProTides $(\mathbf{3 9}, \mathbf{4 1}, \mathbf{4 2}$, and $\mathbf{4 5})$ showed an anti-HIV activity in a range between $10-95 \mu \mathrm{M}$ and cytotoxicity $\geq 100 \mu \mathrm{M}$. The phenyl-L-alaninyl- $O$-benzyl derivative 
42 was the most active of this series, with an $\mathrm{EC}_{50}=10 \mu \mathrm{M}$ and $\mathrm{IC}_{50}=>150 \mu \mathrm{M}$. Its therapeutic selectivity index (i.e. ratio $\mathrm{IC}_{50} / \mathrm{EC}_{50}$ ) was $>15$. The substitution of the natural amino acid L-alanine with the non-natural amino acid dimethylglycine led to a > 4-fold reduction of anti-HIV activity. As observed in the previous series, the bis-ProTides of 2 (3638) and the 2- $\mathrm{NH}_{2}$-DMF-protected ProTides $\mathbf{3 0}$ and $\mathbf{3 1}$ were generally fairly cytotoxic (4-30 $\mu \mathrm{M})$ and the antiviral activity observed may be due to the underlying cytotoxicity.

The $\mathbf{3}$ bis-ProTides $\mathbf{5 4}$ and $\mathbf{5 5}$ was highly cytotoxic ( 21 and $4 \mu \mathrm{M}$, respectively) which, as previously observed, may affect the apparent anti-HIV activity.

In the 6-chloropenciclovir 4 ProTides series, mono-ProTide $\mathbf{6 0}$ showed an anti-HIV activity in the low micromolar range $(1 \mu \mathrm{M})$ and an $\mathrm{IC}_{50}=20 \mu \mathrm{M}$, while bis-ProTide 59 showed a 7fold loss in antiviral activity while retaining cytotoxicity.

6-Methoxy-penciclovir 5 mono-ProTides (66-72) showed an $\mathrm{EC}_{50}$ in a range between 1.1$>150 \mu \mathrm{M}$, and an $\mathrm{IC}_{50}$ in between 12-92 $\mu \mathrm{M}$. It must be stated that the majority of the compounds showed a substantial antiproliferative effect and the observed anti-HIV activity may result from it, with the exception of compound $\mathbf{6 6}$, which showed the best inhibitory activity $\left(\mathrm{EC}_{50}=1.1 \mu \mathrm{M}\right)$ as well as the best selectivity index $=21$. Interestingly, the substitution of the phenyl moiety with the naphthol led to a dramatic loss of activity (>20 fold), which was not observed in the previous series. Regarding the bis-ProTides (61-65), these compounds were found to be fairly cytotoxic.

The cyclic ProTides $\mathbf{7 4}$ and $\mathbf{7 5}$ were also evaluated in this study, showing an $\mathrm{EC}_{50}=22 \mu \mathrm{M}$ and $\mathrm{IC}_{50}=>150 \mu \mathrm{M}$ (selectivity index $>7$ ) for compound 74 , and $\mathrm{EC}_{50}=85 \mu \mathrm{M}$ and $\mathrm{IC}_{50}$ of $150 \mu \mathrm{M}$ for $\mathbf{7 5}$.

The monoacetyl ProTide $\mathbf{7 7}$ was designed to elucidate the mechanism of bioactivation of the ProTides, which will be discussed later. While the parent compound $\mathbf{7 6}$ did not show any anti-HIV activity or cytotoxicity $\left(\mathrm{EC}_{50}\right.$ and $\left.\mathrm{IC}_{50}>150 \mu \mathrm{M}\right)$, ProTide 77 showed an $\mathrm{EC}_{50}=2$ $\mu \mathrm{M}$ for HIV and an $\mathrm{IC}_{50}=10 \mu \mathrm{M}$, data similar to its related compound $\mathbf{6 0}$.

We then next tested a selection of ProTides and their respective parent nucleosides using $e^{X}$ vivo human tonsillar tissues infected with HIV and HHV, as previously described. ${ }^{3}$ This system of histoculture offers major advantages over single cell cultures as explants retain tissue cytoarchitecture and many important functional aspects of cell-cell interactions in vivo. In particular, cultures of human lymphoid tissue allow the testing of anti-HIV drugs upon HIV inoculation ex vivo, as tissue explants support productive HIV infection without exogenous cell activation, and retain the pattern of expression of key cell surface molecules relevant to HIV infection. ${ }^{23}$ In this assay, $\mathbf{1}$ proved to be fairly effective in inhibiting HIV at an $\mathrm{EC}_{50}=5 \mu \mathrm{M}$. Compounds 28 and 74, respectively the mono-ProTide and the cyclicProTide of $\mathbf{1}$, showed retention of antiviral activity $\left(\mathrm{EC}_{50}=11\right.$ and $4.6 \mu \mathrm{M}$, respectively) showing that the delivery of the monophosphate form of ganciclovir through a Protide is as efficient as the phosphorylation mediated by the HHV-TK present in the tissue culture. 2 displayed an $\mathrm{EC}_{50}=11 \mu \mathrm{M}$ versus $\mathrm{HIV}-1$. This was expected since $\mathrm{PCV}$ is a well-known anti-HSV drug and as such it is a good substrate for the HHV-thymidylate kinase. This 
activity was also in accordance with the results obtained for its ProTide $\mathbf{4 2}$ in the MT4 assay $\left(\mathrm{EC}_{50}=10 \mu \mathrm{M}\right)$. An interesting result was obtained for compound $\mathbf{3}$ which lacked any antiHIV activity $\left(\mathrm{EC}_{50}>30 \mu \mathrm{M}\right)$ in this assay, although it functions as a submicromolar HSV inhibitor (as reported in Table 3). Similar results were obtained for its bis-ProTide 55, which did not inhibit HIV either. We can speculate that $\mathbf{3}$, despite being a very close analogue of 1 , is not a good substrate for HIV RT and the inhibitory activity found in the MT-4 cell assay for $\mathbf{5 4}$ and $\mathbf{5 5}$ was just due to the underlying toxicity of these compounds.

Both compounds 4 and 5 were not effective in this assay $\left(\mathrm{EC}_{50}>60 \mu \mathrm{M}\right.$ and $>30 \mu \mathrm{M}$, respectively), while their phosphate prodrugs were able to inhibit HIV in a low micromolar range $\left(\mathrm{EC}_{50}=4 \mu \mathrm{M}\right.$ for mono-ProTide $\mathbf{6 0}$ and $\mathrm{EC}_{50}=9 \mu \mathrm{M}$ for cyclic ProTide $\mathbf{7 4}$ (both derivatives of nucleoside analogue 4) and $\mathrm{EC}_{50}=0.9 \mu \mathrm{M}$ for $\mathbf{6 6}$ (mono-ProTide of $\mathbf{5}$ ). The lack of activity reported for $\mathbf{4}$ and $\mathbf{5}$ is probably related to their poor conversion to the monophosphate form by TK-HHV. This assumption is supported by the lack of anti-HSV activity of these compounds (Table 3). The same result was obtained for the monoacetylated derivative $76\left(\mathrm{EC}_{50}>10 \mu \mathrm{M}\right)$, while its ProTide 77 showed an $\mathrm{EC}_{50}=4 \mu \mathrm{M}$.

\section{Anti-HSV activity}

The synthesised compounds were also evaluated for their ability to inhibit HSV-1, HSV-2, and a thymidine kinase-deficient ( $\mathrm{TK}^{-}$) HSV-1 strain (ACV-resistant) in confluent virusinfected human embryonic lung fibroblast (HEL) cell cultures (Table 3). Parental ganciclovir 1 showed an antiviral activity $\left(\mathrm{EC}_{50}\right)$ of $0.03 \mu \mathrm{M}, 0.04 \mu \mathrm{M}$ and $4.3 \mu \mathrm{M}$ respectively against HSV-1, HSV-2 and HSV-1 TK ${ }^{-}$, respectively. Similar to the anti-HIV activity in tissues $e x$ vivo, its ProTides were found to be slightly less active compared to the parent nucleoside (with an activity against the HSV-1 Kos strain in the range of 0.09-2 $\mu \mathrm{M}$ for the monoProTides 16, 20, 22, 27 and 28, and in the range of $0.3-3 \mu \mathrm{M}$ for the bis-ProTides 15, 17, 19 and 21). Similar activity was obtained against HSV-2 with an $\mathrm{EC}_{50}$ in the range of $0.3-3 \mu \mathrm{M}$ for the mono-ProTides, and 0.9-2.5 $\mu \mathrm{M}$ for the bis-ProTides. As expected, while the parent nucleoside 1 showed a loss of activity of $\sim 140$-fold against HSV-1 TK${ }^{-}$, some of the ProTides (mono- and bis-) showed a good retention of the antiviral activity against this strain. In particular, compounds 18, 19, 20 and 22 showed a full retention of antiviral activity ( $<2.5$ fold difference in $\mathrm{EC}_{50}$ values between $\mathrm{HSV}-1 \mathrm{TK}^{+}$and $\mathrm{TK}^{-}$strains). While compounds 17, 21 and 28 still show considerable activity against these two HSV-1 strains, compounds $\mathbf{1 5}$ and $\mathbf{1 6}$ displayed marginal activity against the $\mathrm{TK}^{-}$mutant virus. No cytotoxicity was observed for any of these compounds (MCC > $100 \mu \mathrm{M}$ ).

It must be stated that in spite of being at least 15-fold (HSV-1) and 30-fold (HSV-2) less potent than the parent nucleoside, the majority of these compounds were found as active as $+\mathrm{ACV}$, the current drug treatment of choice for HSV infections.

Penciclovir (2) mono-ProTides 39, 41, 42, and $\mathbf{4 5}$ showed a loss of antiherpes activity of 16- to 150-fold against wild-type HSV-1 and 27- to 132-fold against HSV-2 compared to the parent nucleoside $\left(\mathrm{EC}_{50}=0.5,0.6\right.$ and $4 \mu \mathrm{M}$ against HSV-1, HSV-2 and HSV-1 TK ${ }^{-}$ strain, respectively). In addition, no activity was found for the mono-ProTides of $\mathbf{2}$ against the HSV-TK ${ }^{-}$strain. Contrary to the observed GCV results, bis-ProTides of $\mathbf{2}$ (compounds 
30, 31, 37, 38, and 40) were found to be inactive against the three HSV strains. Similarly, compounds 54 and 55 (i.e. bis-ProTides of $\mathbf{3}$ ) were found inactive $\left(\mathrm{EC}_{50}>100 \mu \mathrm{M}\right)$ against HSV-1 and HSV-2, while the parent compound 3 showed a sub-micromolar activity.

Compound 5 did not show any anti-HSV activity $\left(\mathrm{EC}_{50}>100 \mu \mathrm{M}\right)$. Its mono-ProTide derivatives, with the exception of compound $\mathbf{7 0}$, which showed a good to moderate inhibitory activity $\left(\mathrm{EC}_{50}=9-38 \mu \mathrm{M}\right.$ and $\mathrm{EC}_{50}=9-20 \mu \mathrm{M}$ against HSV-1 and HSV-2, respectively), with retention of some activity against the $\mathrm{TK}^{-}$strain for compounds 66,67 , 68, and72. Compound 68, bearing the naphthyl as an aryl group, L-alanine as an amino acid and neopentyl as an ester, showed the best antiviral profile with an $\mathrm{EC}_{50}$ of $9 \mu \mathrm{M}, 9 \mu \mathrm{M}$ and $15 \mu \mathrm{M}$ against HSV-1, HSV-2 and HSV-TK ${ }^{-}$, respectively. In this series, as already observed for derivatives of $\mathbf{2}$ and 3 , the bis-ProTides $61,62,63,64$, and 65 were found totally inactive $\left(\mathrm{EC}_{50}>100 \mu \mathrm{M}\right)$.

\section{Anti-HCMV activity}

The synthesised compounds were also evaluated for their ability to inhibit two strains (AD-169 and Davis) of human cytomegalovirus (HCMV) in confluent HEL cell cultures (Table 4). Compound 1 showed an $\mathrm{EC}_{50}$ of $7.4 \mu \mathrm{M}$ (AD-169 strain) and $7.3 \mu \mathrm{M}$ (Davis strain); its mono-ProTides showed an $\mathrm{EC}_{50}$ in a range between 6.6->50 $\mu \mathrm{M}$ (AD-169 strain) and in a range between 4.9-23.6 $\mu \mathrm{M}$ (Davis strain); the bis-ProTides showed a loss of activity compared to the mono-ProTides. Compounds 22, 27 and 28 were the most active of this series with $\mathrm{EC}_{50} \mathrm{~s}$ comparable to that of the parent nucleoside. Compounds $\mathbf{2}$ and $\mathbf{3}$ and their ProTides showed poor, if any activity against HCMV $\left(\mathrm{EC}_{50} \geq 50 \mu \mathrm{M}\right)$. The 6-methoxyPCV 5 did not show any activity against HCMV $\left(\mathrm{EC}_{50}>50 \mu \mathrm{M}\right)$, while some mono- and bis-ProTides showed a moderate anti-HCMV activity, which, however, could be related to the cytotoxicity of these compounds $\left(\mathrm{CC}_{50}\right.$ s in the range of 1.6 to $\left.\geq 83 \mu \mathrm{M}\right)$.

\section{Anti-VZV activity}

A biological evaluation against two strains (OKA and $07-1 \mathrm{TK}^{-}$) of VZV was also performed in monolayer HEL cell cultures (Table 4). Compounds $\mathbf{2 0}$ and $\mathbf{2 7}$ emerged as the most potent mono-ProTides of $\mathbf{1}$ with a good antiviral activity against VZV in the low $\mu \mathrm{M}$ range for both strains $\left(\mathrm{EC}_{50}=7.3 \mu \mathrm{M}\right.$ against the $\mathrm{TK}^{+} \mathrm{VZV}$ strain Oka) and excellent retention of activity against the $\mathrm{TK}^{-} \mathrm{VZV}$ strain $07-1\left(\mathrm{EC}_{50}=3.2-3.3 \mu \mathrm{M}\right)$. These compounds were slightly less active than the current drug treatment of choice (ACV) against the $\mathrm{TK}^{+}$-OKA strain. However, they showed to be at least $\sim 20$ fold more active against the ACV-resistant VZV TK ${ }^{-}$07-1 strain.

Both mono- and bis-ProTides of $\mathbf{2}$ showed at least a 10-fold loss of anti-VZV activity compared to the parent compound and proved also poorly effective against the TK-deficient VZV strain. Similarly, poor activity was also found for ProTides $\mathbf{5 4}$ and $\mathbf{5 5}$. None of the mono- and bis-ProTides of 4 and 5 displayed interesting anti-VZV activity at non-toxic concentrations. 


\section{Mechanism of bioactivation of ProTides}

The putative mechanism of bioactivation of the phosphoramidate ProTide moiety involves two subsequent enzymatic steps (Scheme 13). The ester moiety of a general ProTide depicted as $\mathbf{7 8}$ (red) is cleaved by an esterase- or carboxypeptidase-type enzyme to give compound 79 (blue). The negatively charged oxygen attacks the phosphorous with the release of the aryl moiety forming the unstable mixed anhydride $\mathbf{8 0}$ (magenta), which is consequently opened by water yielding compound $\mathbf{8 1}$ (green). The phosphorous-nitrogen bond of $\mathbf{8 1}$ is then cleaved by a phosphoramidase-type enzyme to release the monophosphate form $\mathbf{8 2}$ (yellow).

The first bioactivation step for a selection of mono- and bis- ProTides as well as cyclic derivative 75 was investigated. This experiment involved the incubation of the appropriate compound with carboxypeptidase $\mathrm{Y}$ using ${ }^{31} \mathrm{P}-\mathrm{NMR}$ to follow the metabolism of the starting material. For all the experiments a ${ }^{31} \mathrm{P}-\mathrm{NMR}$ of the starting material was registered prior to the addition of the enzyme, and then ${ }^{31} \mathrm{P}-\mathrm{NMR}$ spectra were registered every 5-10 min for a minimum period of $14 \mathrm{~h}$. This experiment allowed understanding whether any lack of antiviral activity was due to a poor activation of the ProTide moiety with the subsequent low conversion to the monophosphate form.

Compound $\mathbf{1 6}$ (Figure 6, red) showed a slow and incomplete conversion to the metabolite $\mathbf{8 1}$ $\left(\delta_{\mathrm{P}}=7\right.$, green $)$, which appeared within $1 \mathrm{~h}$ of incubation with the enzyme. After $24 \mathrm{~h}$, the starting compound 16 was still well-detected. Therefore, a partial conversion of the starting material into the first metabolite could be noticed.

Also for compound 45 (Figure 7), a slow and incomplete conversion of the starting material (red) to the metabolite $\mathbf{8 1}\left(\delta_{\mathrm{P}}=7.5\right.$, green) was observed. The formation of the intermediate metabolite $79\left(\delta_{\mathrm{P}}=4.16,4.08,4.00\right.$, blue $)$ was observed and its disappearance indicated its conversion to the desired metabolite 81. Interestingly, the formation of an unknown species $\left(\delta_{P}=5.67,5.59\right.$, orange $)$ was observed after $15 \mathrm{~min}$ and constantly increased with time.

Compound 63 (Figure 8, red), as an example of a bis-ProTide, showed a fast conversion to the first metabolite $\mathbf{7 9}$ (blue), which was then partially converted to the second metabolite $\mathbf{8 1}$ (green). Notably, the presence of two peaks $\left(\delta_{P}=7.00,7.20\right)$ reflect the presence of two phosphorus groups.

As depicted in Figure 9, the mono-ProTide 69 showed a complete conversion of the starting material (red) within $2 \mathrm{~h}$ from the start of the experiment to the desired metabolite (green). The intermediate 79 (blue) was barely detectable indicating a fast conversion to metabolite 81. As already observed for other mono-ProTides, an unknown species at $\delta_{P}=\sim 5.5$ (orange) did also appear in this experiment.

Compound 60 (Figure 10, red) was completely converted within 30 min upon the addition of the enzyme to the desired metabolite $\left(\delta_{\mathrm{P}}=\sim 7.0\right.$, green), through the intermediate $\mathbf{7 9}$ (blue). Also in this case, the species at $\delta_{\mathrm{P}}=5.5,5.6$ (orange) was formed and increased in the first 30 minutes of the experiment and then appeared to remain constant for the whole duration of the experiment. In this experiment, it is easy to note two distinct peaks, which is usually 
related to the presence of a chiral phosphorous. In addition, this compound did not seem to be a substrate for the carboxypeptidase since the addition of two extra portions of enzyme did not have any effect on this compound. The enzymatic studies performed showed a partial (compounds 16, 45, and 63) to full (compounds 60 and 69) conversion of the starting material to the desired metabolite $\mathbf{8 1}$ and the unknown species at 5-5.5 ppm. We hypothesise that this unknown species corresponds to the product of intramolecular cyclisation with the 3 '-OH attacking the phosphorus center, and being in competition with the carboxylate released by the enzymatic cleavage.

To investigate and confirm this pathway, an enzymatic experiment was designed and performed using the cyclic derivative $\mathbf{7 5}$ (Scheme 14), and its conversion was monitored by ${ }^{31} \mathrm{P}-\mathrm{NMR}$ (Figure 11) as well as by mass spectroscopic analysis.

Within $1 \mathrm{~h}$, compound 75 (Figure 11, red) was completely metabolised to the first intermediate lacking the ester moiety $\left(\delta_{\mathrm{P}}=5.3,5.4 \mathrm{ppm}\right.$, orange) and having similar chemical shift as the unknown species observed in the previous experiments. The identity of this compound was supported by mass spectroscopic analysis $\left(\mathrm{M}+\mathrm{H}^{+}: 404\right)$. The conversion to the final metabolite 84 ( $\delta_{\mathrm{P}}=\sim 7.0$, green) was observed after $2.5 \mathrm{~h}$ and it appeared to be the only species after $8 \mathrm{~h}$. Mass spectroscopic analysis confirmed the formation of the metabolite $84\left(\mathrm{M}+2 \mathrm{Na}^{+}: 467\right)$. From these results, we can now confidently postulate that the formation of the peak at 5-5.5 ppm observed for the compounds analysed can be attributed to the formation of the corresponding cyclic intermediate, due to an intramolecular competition between the 3'-OH versus the carboxylate, which did not lead to the formation of the desired compound indicated in Figure 6 as $\mathbf{8 1}$. Interestingly, intermediate $\mathbf{8 3}$ can still undergo attack from the carboxylate to the phosphorus followed by water-mediated opening of the mixed anhydride resulting in the formation of metabolite $\mathbf{8 4}$.

To further support this hypothesis, the monoacetylated ProTide $\mathbf{7 7}$ was also studied (Figure 12). The compound proved to be a good substrate for the carboxypeptidase and it was quickly metabolised to the intermediate $\left(\delta_{\mathrm{P}}=4.35,4.28,4.16 \mathrm{ppm}\right.$, blue) followed by spontaneous conversion to the desired metabolite $\left(\delta_{\mathrm{P}}=\sim 7.0\right.$, green $)$. As anticipated, the formation of an unknown species at 5-5.5 ppm was not observed supporting our hypothesis of the need of a free 3'-OH to form this metabolite.

It is worth to note the fast conversion of only one diastereoisomer, whilst the metabolism of the other three proceeded more slowly, although a full conversion was observed within $12 \mathrm{~h}$. The difference in the rate of conversion for the different diastereoisomers had already been observed previously. ${ }^{4}$ Docking studies using the carboxypeptidase $\mathrm{Y}$ enzyme showed indeed the ability of the enzyme to discriminate between diasteroisomers. ${ }^{4}$

\section{Conclusion}

We previously showed that the anti-herpetic drug ACV, an acyclic nucleoside analogue, has direct anti-HIV suppressive activity ex vivo ${ }^{2}$ and in vivo. ${ }^{24}$ The anti-HIV activity of ACV is dependent on its prior phophorylation by HHV TK. To bypass this requirement, we developed a series of ACV ProTides that showed pronounced anti-HIV activity, low toxicity 
but somewhat cytostatic activity. ${ }^{4}$ Here, to overcome this issue and assess the potential of acyclic nucleoside analogues as anti-HIV drugs, we performed a virtual screening of a library of acyclic nucleoside derivatives. Docking experiments with a database of 3,600 compounds against three different enzymes (HIV RT, adenylate or guanylate kinase and a model of DNA polymerase $\gamma$ ) resulted in 5 compounds that potentially were the strongest RT inhibitors and the weakest cellular DNA polymerase inhibitors. The five compounds selected were: ganciclovir (1), penciclovir (2), the 2'-thio derivative of ganciclovir (3), 6chloropenciclovir (4), and 6-methoxypenciclovir (5). Altogether, 39 phosphate prodrugs were synthesised and assessed for their potency against HIV and three HHVs, namely HSV, VZV and CMV. Most of the compounds were inhibitory against HIV with activity in the low $\mu \mathrm{M}$ range, but some toxicity was observed, except for compound $\mathbf{6 6}$. Some of the mono- and bis-ProTides of $\mathbf{1}$ were active against HSV, VZV and CMV, but not superior to ACV. Interestingly, they were also active against their TK-deficient counterparts, which is an advantage over ACV. Mono- and bis-ProTide derivatives of compounds 2, 3 and $\mathbf{5}$ did not display important acitivty against HHVs tested in this study.

Finally, we investigated the mechanism of bioactivation for these compounds using a wellestablished enzymatic assay. The majority of the compounds was found to be substrate for the first enzyme involved in the activation pathway to release the intermediate indicated in Scheme 13 as compound $\mathbf{8 1}$. However, in some cases formation of a stable 3'-5'-cyclicphosphate was also observed; the formation of this compound was supported by experiments depicted in Figure 11 and 12.

\section{Experimental Section}

All anhydrous solvents were purchased from Sigma-Aldrich and amino acid esters from Novabiochem. All commercially available reagents were used without further purification. Thin Layer Chromatography (TLC): precoated aluminium-backed plates (60 F254, $0.2 \mathrm{~mm}$ thickness, Merck) were visualized under both short- and long-wave UV light (254 and 366 $\mathrm{nm})$. Flash column chromatography was carried-out using silica gel supplied by Fisher $(60 \mathrm{~A}, 35-70 \mu \mathrm{m})$. Analytical and semipreparative High Performance Liquid Chromatography (HPLC) analysis was performed using either a ThermoScientific or a Varian Prostar 335 LC detector system using Varian Polaris C18-A $(10 \mu \mathrm{M})$ as an analytical column and Varian Polaris C18-A $(10 \mu \mathrm{M})$ as a semipreparative column. ${ }^{1} \mathrm{H}-\mathrm{NMR}$ (500 $\mathrm{MHz}),{ }^{13} \mathrm{C}-\mathrm{NMR}(125 \mathrm{MHz}),{ }^{31} \mathrm{P}-\mathrm{NMR}(202 \mathrm{MHz})$ spectra were recorded on a Bruker Avance $500 \mathrm{MHz}$ spectrometer at $25^{\circ} \mathrm{C}$. Chemical shifts $(\delta)$ are quoted in parts per million (ppm) relative to internal MeOD ( $\delta 3.341 \mathrm{H} \mathrm{NMR}, \delta 49.8613 \mathrm{C} \mathrm{NMR}$ ) and $\mathrm{CDCl} 3$ ( $\delta 7.26$ 1H NMR, $\delta 77.36$ 13C NMR) or external 85\% H3PO4 ( $\delta 0.00$ 31P NMR). Coupling constants $(\mathrm{J})$ are given in Hertz. The following abbreviations are used in the assignment of NMR signals: s (singlet), d (doublet), $t$ (triplet), q (quartet), qn (quintet), $m$ (multiplet), bs (broad singlet), dd (doublet of doublet), dt (doublet of triplet). Low-resolution and highresolution mass spectrometry was performed on a Bruker Daltonics microTof-LC system, as a service by the School of Chemistry at Cardiff University. Compound purity was assured by a combination of high field multinuclear NMR $(\mathrm{H}, \mathrm{C}, \mathrm{P})$, elemental analysis and/or HPLC. Purity by the later was always $>95 \%$ with no detectable parent nucleoside for all final products. 


\section{Chemistry}

\section{Standard Procedure A: Synthesis of Phosphoramidates}

To a stirring suspension of appropriate nucleoside ( $1.00 \mathrm{~mol} /$ equiv) in anhydrous THF, a $1.0 \mathrm{M}$ solution of ${ }^{\mathrm{t}} \mathrm{BuMgCl}$ ( $\left.2.00 \mathrm{~mol} / \mathrm{equiv}\right)$ in THF was added dropwise under an argon atmosphere and the reaction mixture was stirred at room temperature for $30 \mathrm{~min}$. Then the appropriate phosphorochloridate (1.50 to $4.00 \mathrm{~mol} /$ equiv) was added dropwise a solution of in anhydrous THF. The reaction mixture was stirred at room temperature for $24-84 \mathrm{~h}$. The solvent was removed under reduced pressure, and the residue was purified by column chromatography.

\section{Synthesis of $N^{\prime}-(9-\{[(1,3-d i h y d r o x y p r o p a n-2-y l) o x y] m e t h y l\}-6-0 x o-6,9-$} dihydro-1H-purin-2-yl)-N,N-dimethylmethanimidamide (6)-To a suspension of $\mathbf{1}$ $(0.50 \mathrm{~g}, 1.96 \mathrm{mmol})$ in anhydrous DMF $(10 \mathrm{~mL})$ was added $N, N$-dimethylformamide dimethyl acetal $(1.30 \mathrm{~mL}, 9.79 \mathrm{mmol})$ and the reaction mixture was stirred at room temperature for $22 \mathrm{~h}$. After this period was added $N, N$-dimethylformamide dimethyl acetal $(0.65 \mathrm{~mL}, 4.90 \mathrm{mmol})$ and the suspension was stirred at room temperature for $7 \mathrm{~h}$. The suspension was then filtered, and the solid was washed with diethyl ether to give a colourless solid (84\%, $0.51 \mathrm{~g}$ ). ${ }^{1} \mathrm{H}-\mathrm{NMR}$ (DMSO $500 \mathrm{MHz}$ ): $\delta 11.31(1 \mathrm{H}, \mathrm{s}, \mathrm{NH}), 8.57(1 \mathrm{H}, \mathrm{s}, 1 \mathrm{H})$, $7.93(1 \mathrm{H}, \mathrm{s}, \mathrm{H}-8), 5.54$ (2H, s, H-1'), 4.64 (2H, bs, 2xOH), 3.66-3.60 (1H, m, H-3'), 3.49-3.43 (4H, m, H-4', H-5'), 3.16, $3.04\left(6 \mathrm{H}, 2 \mathrm{~s}, \mathrm{~N}\left(\mathrm{CH}_{3}\right)_{2}\right)$.

\section{Synthesis of ( $N$-(9-[(1,3-dihydroxypropan-2-yloxy)me-thyl]-6-oxo-6,9-} dihydro-1 H-purin-2-yl)-N,N-dimethylformimidamide)-[1-naphthyl(isopropoxy-Lalaninyl)] diphosphate (7) and $\mathrm{N}^{\prime}$-(9-\{[(1,3-dihydroxypropan-2-yl)oxy]methyl\}-6oxo-6,9-dihydro-1H-purin-2-yl)-N,N-dimethylmethanimidamide-[1naphthyl(isopropoxy-L-alaninyl)] phosphate (8)—Prepared according to Standard Procedure A, from $6(0.25 \mathrm{~g}, 0.81 \mathrm{mmol})$ in anhydrous THF $(15 \mathrm{~mL}),{ }^{\mathrm{t}} \mathrm{BuMgCl}(1.0 \mathrm{M} \mathrm{THF}$ solution, $1.61 \mathrm{~mL}, 1.61 \mathrm{mmol})$, 1-naphthyl-(iso-propoxy-L-alaninyl)-phosphorochloridate $(0.86 \mathrm{~g}, 2.42 \mathrm{mmol})$ in anhydrous THF $(10 \mathrm{~mL})$ and the reaction mixture was stirred at room temperature overnight. After this period pyridine $(5 \mathrm{~mL}),{ }^{\mathrm{t}} \mathrm{BuMgCl}(1.0 \mathrm{M}$ THF solution, $1.61 \mathrm{~mL}, 1.61 \mathrm{mmol}$ ) and 1-naphthyl-(iso-propoxy-L-alaninyl)-phosphorochloridate (1.60 g, $4.49 \mathrm{mmol})$ in anhydrous THF $(10 \mathrm{~mL})$ were added and the reaction mixture was stirred at room temperature for 3 days. The residue was purified by column chromatography gradient elution of $\mathrm{DCM} / \mathrm{MeOH}=98 / 2$, then $95 / 5$, to give 7 as a colourless solid $(44 \%, 0.34 \mathrm{~g}),{ }^{31} \mathrm{P}$ NMR (MeOD, $202 \mathrm{MHz}$ ): $\delta 4.04$ (bs). Compound 8 was obtained as a colourless solid (14\%, $0.071 \mathrm{~g}){ }^{31} \mathrm{P}-\mathrm{NMR}$ (MeOD, $\left.202 \mathrm{MHz}\right): \delta 4.19$ (bs). ${ }^{1} \mathrm{H}-\mathrm{NMR}$ (MeOD, $\left.500 \mathrm{MHz}\right): \delta$ 8.74-8.68 (1H, m, NCHN(CH$\left.)_{2}\right)$, 8.17-7.36 (8H, m, H-8, Naph), 5.73-5.70 (2H, m, H-1'), 4.99-4.80 (1H, bs, $\left.\mathrm{COOCH}\left(\mathrm{CH}_{3}\right)_{2}\right), 4.39-4.05(3 \mathrm{H}, \mathrm{m}, \mathrm{H}-3$ ', H-5'), 3.97-3.88 (1H, m, $\left.\mathrm{CHCH}_{3}\right), 3.70-3.56\left(2 \mathrm{H}, \mathrm{m}, \mathrm{H}-4\right.$ '), 3.20, $3.12\left(6 \mathrm{H}, \mathrm{s}, \mathrm{N}\left(\mathrm{CH}_{3}\right)_{2}\right), 1.33-1.28\left(3 \mathrm{H}, \mathrm{m}, \mathrm{CHCH}_{3}\right)$, 1.22-1.16 (6H, m, $\left.\mathrm{COOCH}\left(\mathrm{CH}_{3}\right)_{2}\right)$.

Synthesis of 2-amino-9-\{[(1,3-dihydroxypropan-2-yl)oxy]methyl\}-6,9dihydro-1H-purin-6-one-[1-naphthyl(isopropoxy-L-alaninyl)] diphosphate (15)

-A solution of 7 ( $0.33 \mathrm{~g}, 0.35 \mathrm{mmol})$ in 2-propanol $(10 \mathrm{~mL})$ was stirred under reflux for 80 
h. After this period the solvent was removed and the residue purified by column chromatography gradient elution of $\mathrm{DCM} / \mathrm{MeOH}=95 / 5$, then $94 / 6$, then $93 / 7$, to give 15 as a colourless solid $(8 \%, 0.025 \mathrm{~g}) .{ }^{31} \mathrm{P}-\mathrm{NMR}(\mathrm{MeOD}, 202 \mathrm{MHz}): \delta 4.29,4.25,4.23,4.17 .{ }^{1} \mathrm{H}-$ NMR (MeOD, 500 MHz): $\delta$ 8.17-8.05 (2H, m, H-8 Naph), 7.85 (2H, m, H-6 Naph), 7.75-7.71 (1H, m, H-8), 7.68-7.34 (10H, m, Naph), 5.41-5.37 (2H, m, H-1'), 4.99-4.87 (2H, $\left.\mathrm{m}, 2 \mathrm{xCH}\left(\mathrm{CH}_{3}\right)_{2}\right)$, 4.27-4.14 (5H, m, H-3', H-4', H-5'), 4.01-3.91 (2H, m, 2xCHCH 3 ), 1.36-1.26 (6H, m, 2xCHCH 3$), 1.21-1.11\left(12 \mathrm{H}, \mathrm{m}, 2 \mathrm{xCOOCH}\left(\mathrm{CH}_{3}\right)_{2}\right) .{ }^{13} \mathrm{C}-\mathrm{NMR}(\mathrm{MeOD}$, $125 \mathrm{MHz}): \delta 20.49,20.56,20.61,20.64,20.69\left(\mathrm{CHCH}_{3}\right), 21.90,22.00,22.02\left(\mathrm{CH}\left(\mathrm{CH}_{3}\right)_{2}\right)$, $51.87\left(\mathrm{CHCH}_{3}\right), 66.51,66.55,66.66,66.70\left(\mathrm{C}^{2}{ }^{\prime}, \mathrm{C}-5{ }^{\prime}\right), 70.23,70.30,70.32$ $\left(\mathrm{COOCH}\left(\mathrm{CH}_{3}\right)_{2}\right), 72.91$ (C-1'), 76.94 (C-3'), 116.13, 116.42, 122.67, 122.70, 122.79, 126.03, 126.55, 127.54, 127.80, 127.86, 128.87 (C-5, C-2 Naph, C-3 Naph, C-4 Naph, C-5 Naph, C-6 Naph, C-7 Naph, C-8 Naph, C-8a Naph), 136.26 (C-4a Naph), 138.42 (C-8), 147.92, 147.98, 150.02 ('ipso' Naph, C-4), 155.64 (C-2), 159.44 (C-6), 174.72 $\left(\mathrm{COOCH}_{2} \mathrm{Ph}\right) . \mathrm{EI} \mathrm{MS}=916.3(\mathrm{M}+\mathrm{Na})$. Anal. Calcd for $\mathrm{C}_{41} \mathrm{H}_{49} \mathrm{~N}_{7} \mathrm{O}_{12} \mathrm{P}_{2}: \mathrm{C}, 55.09 ; \mathrm{H}, 5.53$; $\mathrm{N}, 10.97$. Found: C, 54.62; H, 5.56; N, 10.60.

\section{Synthesis of 2-amino-9-\{[(1,3-dihydroxypropan-2-yl)oxy]methyl\}-6,9- dihydro-1H-purin-6-one-[1-naphthyl(isopropoxy-L-alaninyl)]phosphate (16)-A} solution of $8(0.070 \mathrm{~g}, 0.11 \mathrm{mmol})$ in 2-propanol $(4 \mathrm{~mL})$ was stirred under reflux for $24 \mathrm{~h}$. After this period the solvent was removed and the residue purified by preparative reverse phase HPLC (gradient elution of $\mathrm{H}_{2} \mathrm{O} / \mathrm{CH}_{3} \mathrm{CN}=$ from $100 / 0$ to $0 / 100$ in $35 \mathrm{~min}$ ) to give $\mathbf{1 6}$ as a colourless solid (33\%, $0.021 \mathrm{~g}) .{ }^{31} \mathrm{P}-\mathrm{NMR}$ (MeOD, $\left.202 \mathrm{MHz}\right)$ : $\delta$ 4.40, 4.36, 4.34, 4.27. ${ }^{1} \mathrm{H}-\mathrm{NMR}$ (MeOD, $500 \mathrm{MHz}$ ): $\delta$ 8.20-8.06 (1H, m, Naph), 7.90-7.85 (1H, m, Naph), 7.83-7.79 (1H, m, H-8), 7.75-7.66 (1H, m, Naph), 7.59-7.49 (2H, m, Naph), 7.49-7.36 (2H, m, Naph), 5.51-5.45 (2H, m, H-1'), 5.03-4.94 (1H, m, CH( $\left.\left.\mathrm{CH}_{3}\right)_{2}\right), 4.39-4.11(2 \mathrm{H}, \mathrm{m}, \mathrm{H}-5$ '), 4.05-3.91 (2H, m, H-3', $\mathrm{CHCH}_{3}$,), 3.65-3.47 (2H, m, H-4'), 1.40-1.29 (3H, m, $\mathrm{CHCH}_{3}$ ), 1.26-1.14 (6H, m, $\left.\mathrm{COOCH}\left(\mathrm{CH}_{3}\right)_{2}\right) .{ }^{13} \mathrm{C}-\mathrm{NMR}(\mathrm{MeOD}, 125 \mathrm{MHz}): \delta 20.46\left(\mathrm{~d}, \mathrm{~J}_{C-P}=6.7\right.$ $\left.\mathrm{Hz}, \mathrm{CHCH}_{3}\right), 20.57\left(\mathrm{~d}, \mathrm{~J}_{C-P}=6.7 \mathrm{~Hz}, \mathrm{CHCH}_{3}\right), 20.68\left(\mathrm{~d}, \mathrm{~J}_{C-P}=6.6 \mathrm{~Hz}, \mathrm{CHCH}_{3}\right), 21.90(\mathrm{~d}$, $\left.\mathrm{J}_{C-P}=2.3 \mathrm{~Hz}, \mathrm{CH}\left(\mathrm{CH}_{3}\right)_{2}\right), 21.99\left(\mathrm{~d}, \mathrm{~J}_{C-P}=2.9 \mathrm{~Hz}, \mathrm{CH}\left(\mathrm{CH}_{3}\right)_{2}\right), 51.83\left(\mathrm{CHCH}_{3}\right), 61.78$, 61.92 (2s, C-4'), 67.36 (d, J $C-P=5.4 \mathrm{~Hz}, \mathrm{C}-5$ '), 67.45 (d, J $C-P=5.7 \mathrm{~Hz}, \mathrm{C}-5$ '), 70.17 $\left(\mathrm{COOCH}\left(\mathrm{CH}_{3}\right)_{2}\right), 70.26\left(\mathrm{~d}, \mathrm{~J}_{C-P}=5.6 \mathrm{~Hz}, \mathrm{COOCH}\left(\mathrm{CH}_{3}\right)_{2}\right), 72.89,73.06,(\mathrm{C}-1$ '), $78.95(\mathrm{~d}$, $\left.\mathrm{J}_{C-P}=7.3 \mathrm{~Hz}, \mathrm{C}-3^{\prime}\right), 79.21$ (d, J $\left.C-P=7.6 \mathrm{~Hz}, \mathrm{C}-3^{\prime}\right), 116.31,116.34,116.37,116.40,117.48$, 117.56, 122.70, 122.74, 122.83, 125.98, 126.55, 127.50, 127.78, 127.80, 127.88, 127.93, 128.85 (C-5, C-2 Naph, C-3 Naph, C-4 Naph, C-5 Naph, C-6 Naph, C-7 Naph, C-8 Naph, C-8a Naph), 136.27 (C-4a Naph), 139.70, 139.75 (C-8), 147.97, 148.05 ('ipso' Naph, C-4), $155.72(\mathrm{C}-2), 159.46(\mathrm{C}-6), 174.52\left(\mathrm{COOCH}_{2} \mathrm{Ph}\right) . \mathrm{EI} \mathrm{MS}=597.1832(\mathrm{M}+\mathrm{Na})$. Anal. Calcd for $\mathrm{C}_{25} \mathrm{H}_{31} \mathrm{~N}_{6} \mathrm{O}_{8} \mathrm{P} \cdot \mathrm{H}_{2} \mathrm{O}: \mathrm{C}, 50.68 ; \mathrm{H}, 5.61 ; \mathrm{N}, 14.18$. Found: $\mathrm{C}, 50.75 ; \mathrm{H}, 5.44 ; \mathrm{N}, 13.89$.

\section{Antiviral Activity Assay}

HIV-1 inhibition by compounds was assessed in MT-4 cell cultures and in human tissue ex vivo.

MT-4 cell cultures-One million of MT-4 cells suspended in $100 \mu \mathrm{L}$ of fresh culture medium were incubated with $100 \mu \mathrm{L}$ (7 ng of p24) of HIV-1 X4 $4_{\text {LAI.04 }}$ viral stock for $2 \mathrm{~h}$ at $37 \mathrm{C}$. After incubation, cells were washed with $20 \mathrm{~mL}$ of PBS and resuspended in $10 \mathrm{~mL}$ of 
fresh medium. $1 \mathrm{~mL}$ of infected cell suspensions were then transferred to microplate wells and tested compounds were added at appropriate concentrations. Cell cultures were then further incubated for 3 days at $37{ }^{\circ} \mathrm{C}$. After 3 days, p24 production was measured in the MT-4 cell culture supernatants.

Human tissue culture ex vivo-Human tonsillar tissues were obtained from patients undergoing routine tonsillectomy at the Children's National Medical Center (Washington DC) under an IRB-approved protocol. Tissues were dissected into 2- to 3- $\mathrm{mm}^{3}$ blocks and placed onto collagen sponge gels in culture medium at the air-liquid interface as described earlier. ${ }^{23}$ Human tonsillar tissues (27 blocks of tissue from each of $n$ donors for each experimental condition) were pretreated with compounds overnight and then infected with HIV-1 X4 $4_{\text {LAI.04 }}$ (Rush University Virology Quality Assurance Laboratory, Chicago, IL). The tissue culture was kept for 12 days, and drugs were replenished after each medium change (every 3 days).

Evaluation of antiviral activity of compounds-We measured p24gag using a beadbased Luminex assay as described earlier. ${ }^{25}$ We then evaluated the antiviral activity of each compound by measuring inhibition of human HIV-1 replication in MT-4 cell cultures and in human lymphoid tissues. For each compound, in MT-4 cell cultures or in lymphoid tissue ex vivo, HIV-1 inhibition at each single concentration was defined by the following formula: inhibition $=(1-\mathrm{Rcompounds} / \mathrm{RCtl}) \times 100$, where Rcompounds and RCtl are the amounts of p24 accumulated in the medium in compound-treated cultures and in untreated cultures, respectively. The results are given as the concentration required to suppress viral replication by $50 \%\left(\left[\mathrm{EC}_{50}\right]\right)$.

The compounds were evaluated against the following viruses: HSV-1 strain KOS, thymidine kinase-deficient $\left(\mathrm{TK}^{-}\right) \mathrm{HSV}-1 \mathrm{KOS}$ strain resistant to $\mathrm{ACV}\left(\mathrm{ACV}^{\mathrm{r}}\right)$, herpes HSV-2 strains Lyons and G, varicella-zoster virus (VZV) strain Oka, TK ${ }^{-}$VZV strain 07-1, human cytomegalovirus (HCMV) strains AD-169 and Davis, and human immunodeficiency virus type 1 strain III $_{\mathrm{B}}$. The antiviral, other than anti-HIV, assays were based on inhibition of virus-induced cytopathicity or plaque formation in human embryonic lung (HEL) fibroblasts. Confluent cell cultures in microtiter 96-well plates were inoculated with 100 $\mathrm{CCID}_{50}$ of virus $\left(\mathrm{CCCID}_{50}\right.$ being the virus dose to infect $50 \%$ of the cell cultures) or with 20 plaque forming units (PFU) (VZV) in the presence of varying concentrations of the test compounds. Viral cytopathicity or plaque formation was recorded as soon as it reached completion in the control virus-infected cell cultures that were not treated with the test compounds. Antiviral activity was expressed as the $\mathrm{EC}_{50}$ (50\% effective concentration) or compound concentration required to reduce virus-induced cytopathogenicity or viral plaque formation by $50 \%$. The MCC (minimal cytotoxic concentration) values were determined as the compound concentration required to afford a microscopically visible alteration of HEL cell morphology.

\section{Cytostatic Activity Assays}

All assays were performed in 96-well microtiter plates. To each well were added (5-7.5) $\times$ $10^{4} \mathrm{CEM}$ cells and a given amount of the test compound. The cells were allowed to 
proliferate for $72 \mathrm{~h}$ at $37{ }^{\circ} \mathrm{C}$ in a humidified $\mathrm{CO}_{2}$-controlled atmosphere. At the end of the incubation period, the cells were counted in a Coulter counter. The $\mathrm{IC}_{50}(50 \%$ inhibitory concentration) was defined as the concentration of the compound that inhibited cell proliferation by $50 \%$.

Viability assays in MT-4 cell cultures. Viability assays were performed in MT-4 cell cultures with the Nucleocounter automated cell counting system (ChemoMetec). The total number of cells and number of dead cells in the cultures untreated and treated with ACV ProTides were enumerated using a propidium iodide-based assay according to the manufacturers' protocol. Data were collected and analyzed using Nucleoview software (Chemometec, Denmark). We defined $\mathrm{CC}_{50}$ as the concentration that reduced the viability of the MT- 4 by $50 \%$ and $\mathrm{IC}_{50}$ as the concentration that inhibited MT-4 or CEM cell growth by $50 \%$

\section{Acknowledgments}

The antiviral research was financially supported by the KU Leuven (GOA 15/19 TBA). We are grateful to Mrs. Leentje Persoons, Mrs. Frieda De Meyer, Mrs. Leen Ingels, Mrs. Lizette van Berckelaer, Mrs. Lies Van den Heurck, Mrs. Anita Camps and Mr. Steven Carmans for excellent technical assistance. We thank the entire staff of the Department of Pathology of Children's National Medical Center for their generous assistance in obtaining human tonsillar tissues.

\section{References}

1. World Health Organization. [access June 2017] http:/www.who.int/gho/hiv/en/

2. U.S. Food and Drug Administration. [access June 2017]

3. Lisco A, Vanpouille C, Tchesnokov EP, Grivel J-C, Biancotto A, Brichacek B, Elliott J, Fromentin E, Shattock R, Anton P, Gorelick R, Balzarini J, McGuigan C, Derudas M, Gotte M, Schinazi RF, Margolis L. Acyclovir is activated into a HIV-1 reverse transcriptase inhibitor in herpesvirusinfected human tissues. Cell Host \& Microbe. 2008; 4:260-270. [PubMed: 18779052]

4. Derudas M, Carta D, Brancale A, Vanpouille C, Lisco A, Margolis L, Balzarini J, McGuigan C. The application of phosphoramidate protide technology to acyclovir confers anti-HIV inhibition. J. Med. Chem. 2009; 52:5520-5530. [PubMed: 19645484]

5. Vanpouille C, Lisco A, Derudas M, Saba E, Grivel J-C, Brichacek B, Scrimieri F, Schinazi R, Schols D, McGuigan C, Balzarini J, Margolis L. A new class of dual-targeted antivirals: monophosphorylated acyclovir prodrug derivatives suppress both human immunodeficiency virus type 1 and herpes simplex virus type 2. J. Infect. Dis. 2010; 201:635-643. [PubMed: 20085496]

6. McGuigan C, Derudas M, Bugert JJ, Andrei G, Snoeck R, Balzarini J. Successful kinase bypass with new acyclovir phosphoramidate prodrugs. Bioorg. Med. Chem. Lett. 2008; 18:4364-4367. [PubMed: 18614365]

7. Tuske S, Sarafianos SG, Clark AD Jr, Ding J, Naeger LK, White KL, Miller MD, Gibbs CS, Boyer PL, Clark P, Wang G, Gaffney BL, Jones RA, Jerina DM, Hughes SH, Arnold E. Structures of HIV-1 RT-DNA complexes before and after incorporation of the anti-AIDS drug tenofovir. Nat. Struct. Mol. Biol. 2004; 11:469-474. [PubMed: 15107837]

8. Bunkoczi G, Filippakopoulos P, Jansson A, Longman E, Von Delft F, Edwards A, Arrowsmith C, Sundstrom M, Weigelt J, Knapp S. Structure of adenylate kinase 1 in complex with P1, P4di(adenosine)tetraphosphate. To be published.

9. Sekulic N, Shuvalova L, Spangenberg O, Konrad M, Lavie A. Structural characterization of the closed conformation of mouse guanylate kinase. J. Biol. Chem. 2002; 277:30236-30243. [PubMed: 12036965]

10. Parker WB, White EL, Shaddix SC, Ross LJ, Buckheit RW, Germany JM, Secrist JA, Vince R, Shannon WM. Mechanism of inhibition of human immunodeficiency virus type 1 reverse transcriptase and human DNA polymerases $a, \beta$, and $\gamma$ by the 5'-triphosphates of carbovir, 3'- 
azido-3'-deoxythymidine, 2',3'-dideoxyguanosine, and 3'-deoxythymidine. J. Biol. Chem. 1991; 266:1754-1762. [PubMed: 1703154]

11. Hart GJ, Orr DC, Penn CR, Figueiredo HT, Gray NM, Boehme RE, Cameron JM. Effects of (-)-2'-deoxy-3'-thiacytidine (3TC) 5'-triphosphate on human immunodeficiency virus reverse transcriptase and mammalian DNA polymerases alpha, beta, and gamma. Antimicrob. Agents Chemother. 1992; 36:1688-1694. [PubMed: 1384425]

12. Martin JL, Brown CE, Matthews-Davis N, Reardon JE. Effects of antiviral nucleoside analogs on human DNA polymerases and mitochondrial DNA synthesis. Antimicrob. Agents Chemother. 1994; 38:2743-2749. [PubMed: 7695256]

13. Copeland WC, Chen MS, Wang TS-F. Human DNA polymerases a and $\beta$ are able to incorporate anti-HIV deoxynucleotides into DNA. J. Biol. Chem. 1992; 267:21459-21464. [PubMed: 1400458]

14. Eriksson S, Xu B, Clayton DA. Efficient incorporation of anti-HIV deoxynucleotides by recombinant yeast mitochondrial DNA polymerase. J. Biol. Chem. 1995; 270:18929-18934. [PubMed: 7642550]

15. Lim SE, Ponamarev MV, Longley MJ, Copeland WC. Structural determinants in human DNA polymerase $\gamma$ account for mitochondrial toxicity from nucleoside analogs. J. Mol. Biol. 2003; 329:45-57. [PubMed: 12742017]

16. Lewis W, Kohler JJ, Hosseini SH, Haase CP, Copeland WC, Bienstock RJ, Ludaway T, McNaught J, Russ R, Stuart T, Santoianni R. Antiretroviral nucleosides, deoxynucleotide carrier and mitochondrial DNA: evidence supporting the DNA pol $\gamma$ hypothesis. AIDS. 2006; 20:675-684. [PubMed: 16514297]

17. Kakuda TN. Pharmacology of nucleoside and nucleotide reverse transcriptase inhibior-induced mitochondrial toxicity. Clin. Ther. 2000; 22:685-708. [PubMed: 10929917]

18. Graziewicz MA, Longley MJ, Bienstock RJ, Zeviani M, Copeland WC. Structure-function defects of human mitochondrial DNA polymerase in autosomal dominant progressive external ophthalmoplegia. Nat. Struct. Mol. Biol. 2004; 11:770-776. [PubMed: 15258572]

19. Uchiyama M, Aso Y, Noyori R, Hayakawa Y. O-selective phosphorylation of nucleosides without N-protection. J. Org. Chem. 1993; 58:373-379.

20. McGee DPC, Martin JC, Smee DF, Matthews TR, Verheyden JPH. Synthesis and antiherpes simplex virus activity of 9-[(1,3-dihydroxy-2-propylthio)methyl]guanine. J. Med. Chem. 1985; 28:1242-1245. [PubMed: 2993615]

21. Torii T, Shiragami H, Yamashita K, Suzuki Y, Hijoya T, Kashiwagi T, Izawa K. Practical synthesis of penciclovir and famciclovir from N2-acetyl-7-benzylguanine. Tetrahedron. 2006; 62:57095716.

22. McGuigan C, Madela K, Aljarah M, Gilles A, Brancale A, Zonta N, Chamberlain S, Vernachio J, Hutchins J, Hall A, Ames B, Gorovits E, Ganguly B, Kolykhalov A, Wang J, Muhammad J, Patti JM, Henson G. Design, synthesis and evaluation of a novel double pro-drug: INX-08189. A new clinical candidate for hepatitis C virus. Bioorg. Med. Chem. Lett. 2010; 16:4850-4854.

23. Grivel J-C, Margolis L. Use of human tissue explants to study human infectious agents. Nat Protoc. 2009; 4:256-269. [PubMed: 19197269]

24. Vanpouille C, Lisco A, Grivel J-C, Bassit LC, Kauffman RC, Sanchez J, Schinazi RF, Lederman MM, Rodriguez B, Margolis L. Valacyclovir Decreases Plasma HIV-1 RNA in HSV-2 Seronegative Individuals: A Randomized Placebo-Controlled Crossover Trial. Clin. Infect. Dis. 2015; 60:1708-1714. [PubMed: 25740794]

25. Biancotto A, Brichacek B, Chen SS, Fitzgerald W, Lisco A, Vanpouille C, Margolis L, Grivel JC. A highly sensitive and dynamic immunofluorescent cytometric bead assay for the detection of HIV-1 p24. J. Virol. Methods. 2009; 157:98-101. [PubMed: 19100289] 
$Q=\mathrm{H}$ or $\mathrm{CH}_{2} \mathrm{OH}$

$=\mathrm{O}, \mathrm{CH}_{2}$ or $\mathrm{S}$

$\mathrm{O}=\mathrm{H}, \mathrm{CH}_{3}, \mathrm{~F}, \mathrm{Br}$ or $\mathrm{Cl}$

$\mathrm{O}=\mathrm{N}, \mathrm{CH}$ or $\mathrm{CCH}_{3}$

$\mathrm{O}=\mathrm{C}=\mathrm{O}, \mathrm{NH}_{2}, \mathrm{Cl}, \mathrm{OCH}_{3}, \mathrm{OCH}_{2} \mathrm{CH}_{3}$,

$\mathrm{HO}$

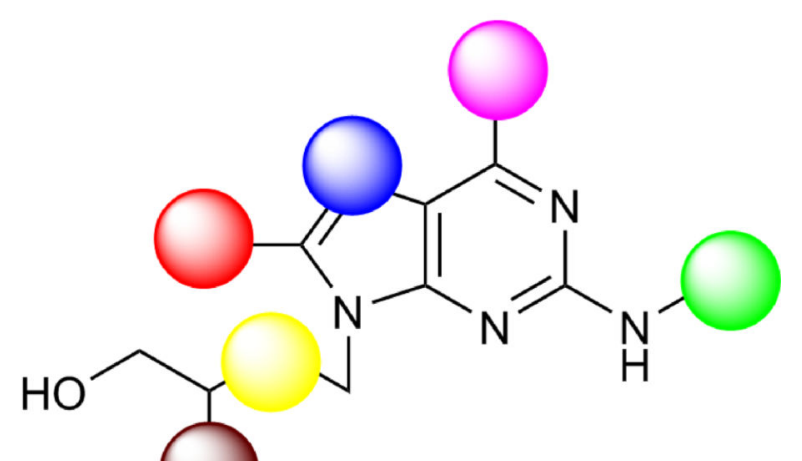
$\mathrm{OPh}, \mathrm{NHCH}_{3}$ or $\mathrm{NH}$-cyclopropyl

$\mathrm{O}=\mathrm{H}, \mathrm{CH}_{3}, \mathrm{CH}_{2} \mathrm{CH}_{3}, \mathrm{Ph}$ or $\mathrm{Bn}$

Figure 1.

Acyclic nucleoside derivatives. 
Derudas et al.

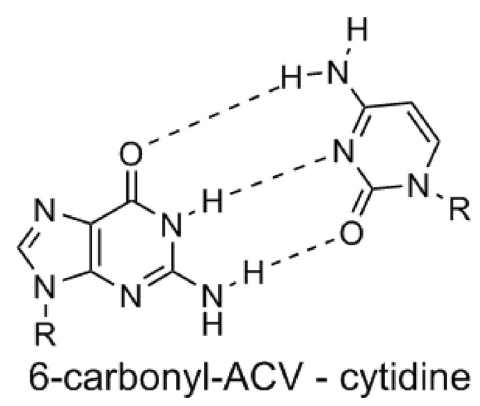

Page 19

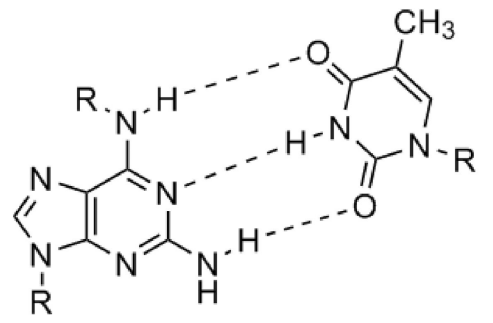

\section{6-O-modified-ACV - thymidine}<smiles></smiles>

Figure 2.

Base-pairing of the 6-carbonyl and 6-modified guanine derivatives. 


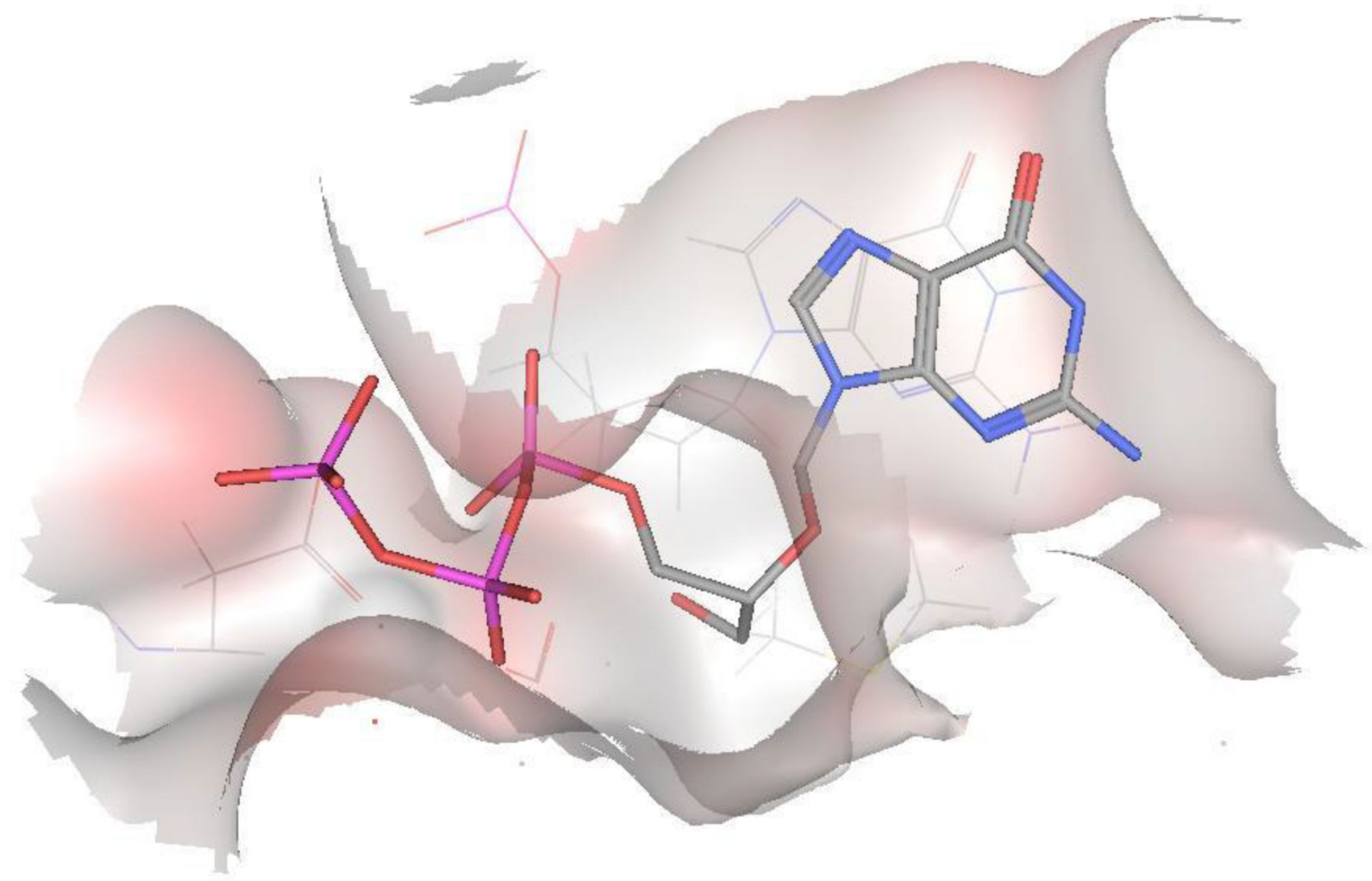

Figure 3.

Docking of GCV within the catalytic site of HIV-RT showed one of the best interactions. 


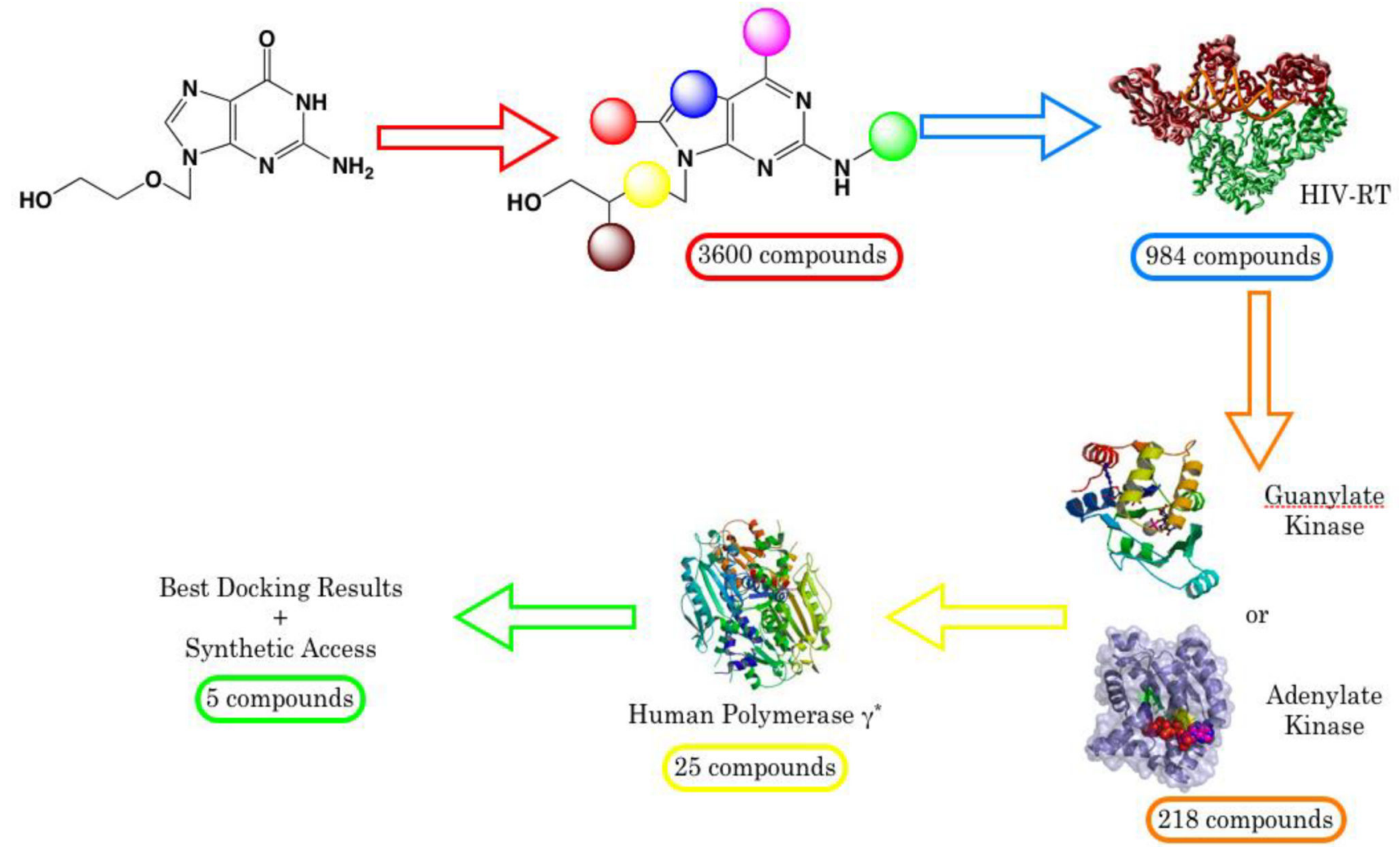

Figure 4.

Summary of the virtual screening using HIV-RT, adenylate or guanylate kinases, and human polymerase $\gamma$. 
<smiles>Nc1nc2c(ncn2COC(CO)CO)c(=O)[nH]1</smiles><smiles>Nc1nc2c(ncn2CCC(CO)CO)c(=O)[nH]1</smiles><smiles>Nc1nc2c(ncn2CSC(CO)CO)c(=O)[nH]1</smiles><smiles>Nc1nc(Cl)c2ncn(CCC(CO)CO)c2n1</smiles><smiles>COc1nc(N)nc2c1ncn2CCC(CO)CO</smiles>

Figure 5.

Selected acyclic nucleoside analogues from the virtual screening. 


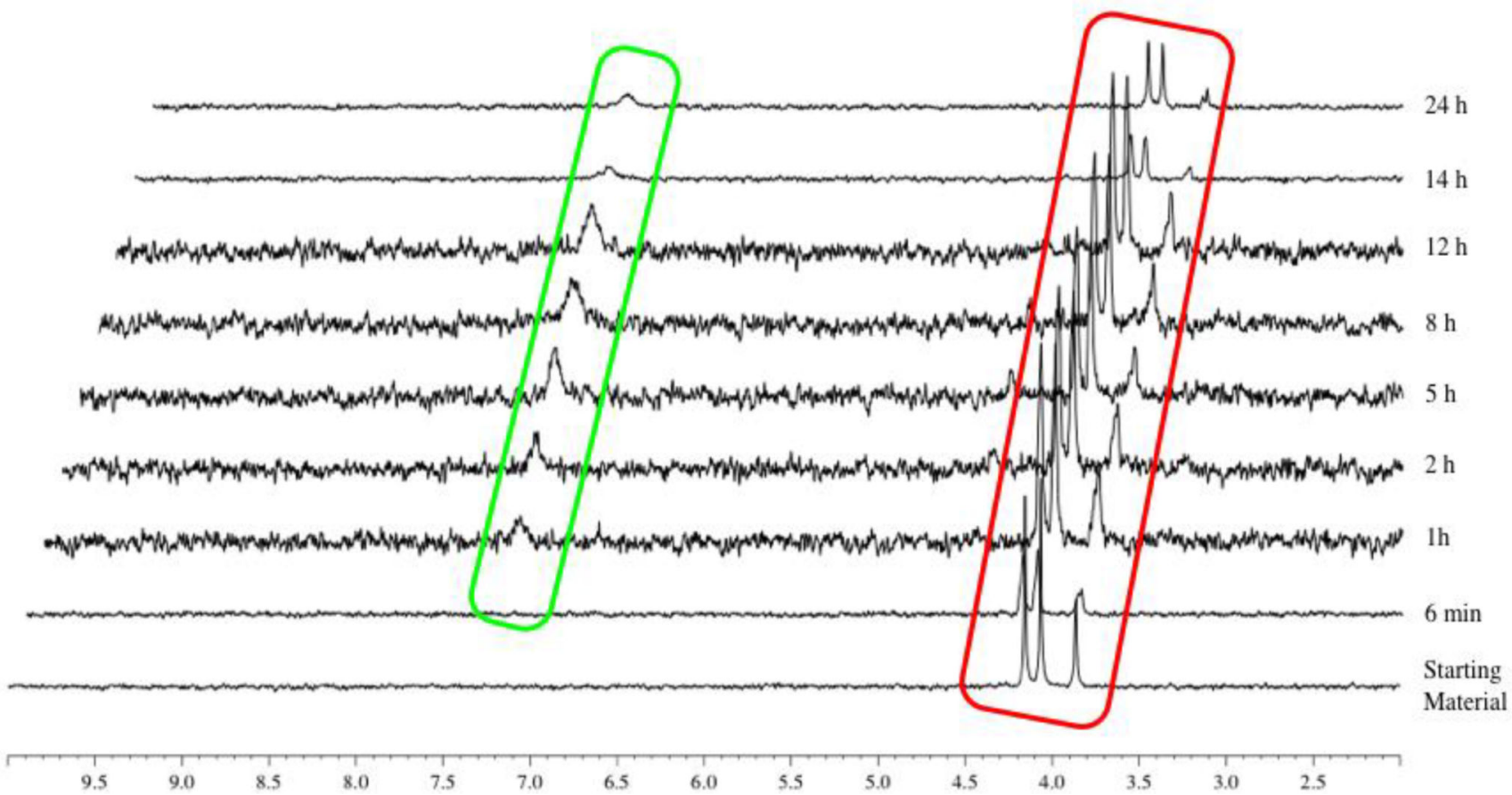

Figure 6.

Carboxypeptidase-mediated cleavage of compound 16, monitored by ${ }^{31} \mathrm{P}-\mathrm{NMR}$. 


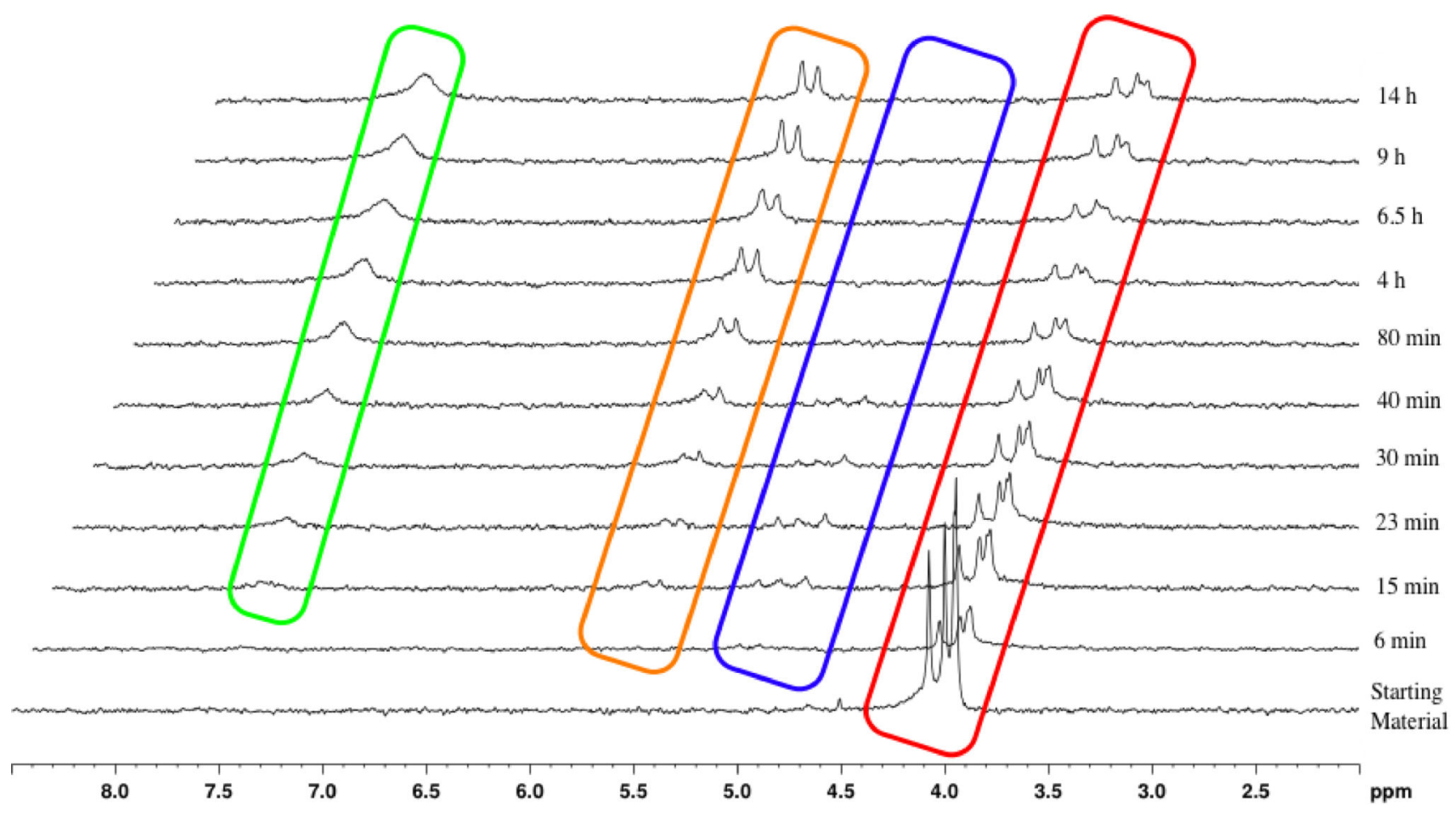

Figure 7.

Carboxypeptidase-mediated cleavage of compound $\mathbf{4 5}$, monitored by ${ }^{31} \mathrm{P}-\mathrm{NMR}$. 


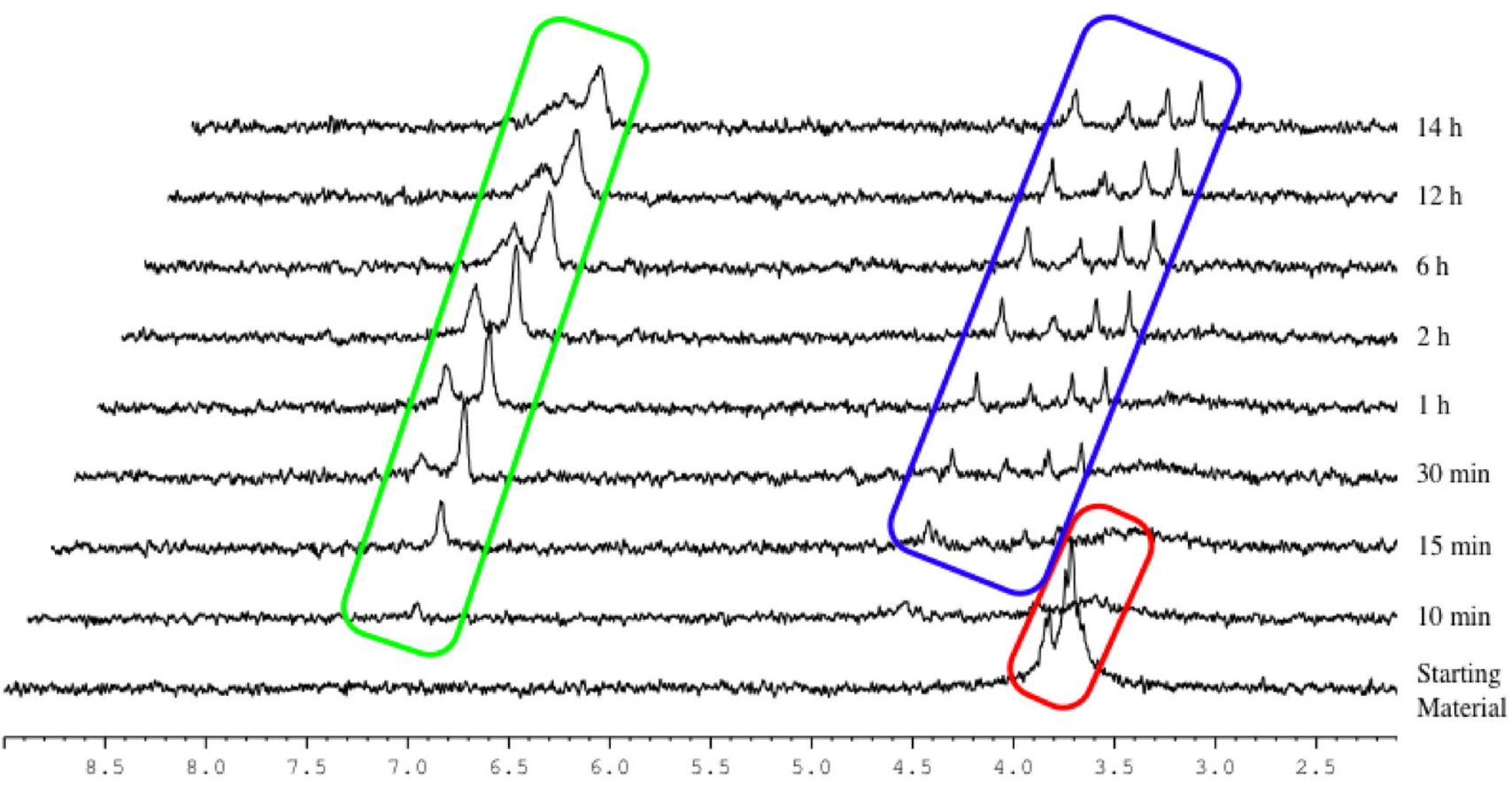

Figure 8.

Carboxypeptidase-mediated cleavage of compound $\mathbf{6 3}$, monitored by ${ }^{31} \mathrm{P}-\mathrm{NMR}$. 


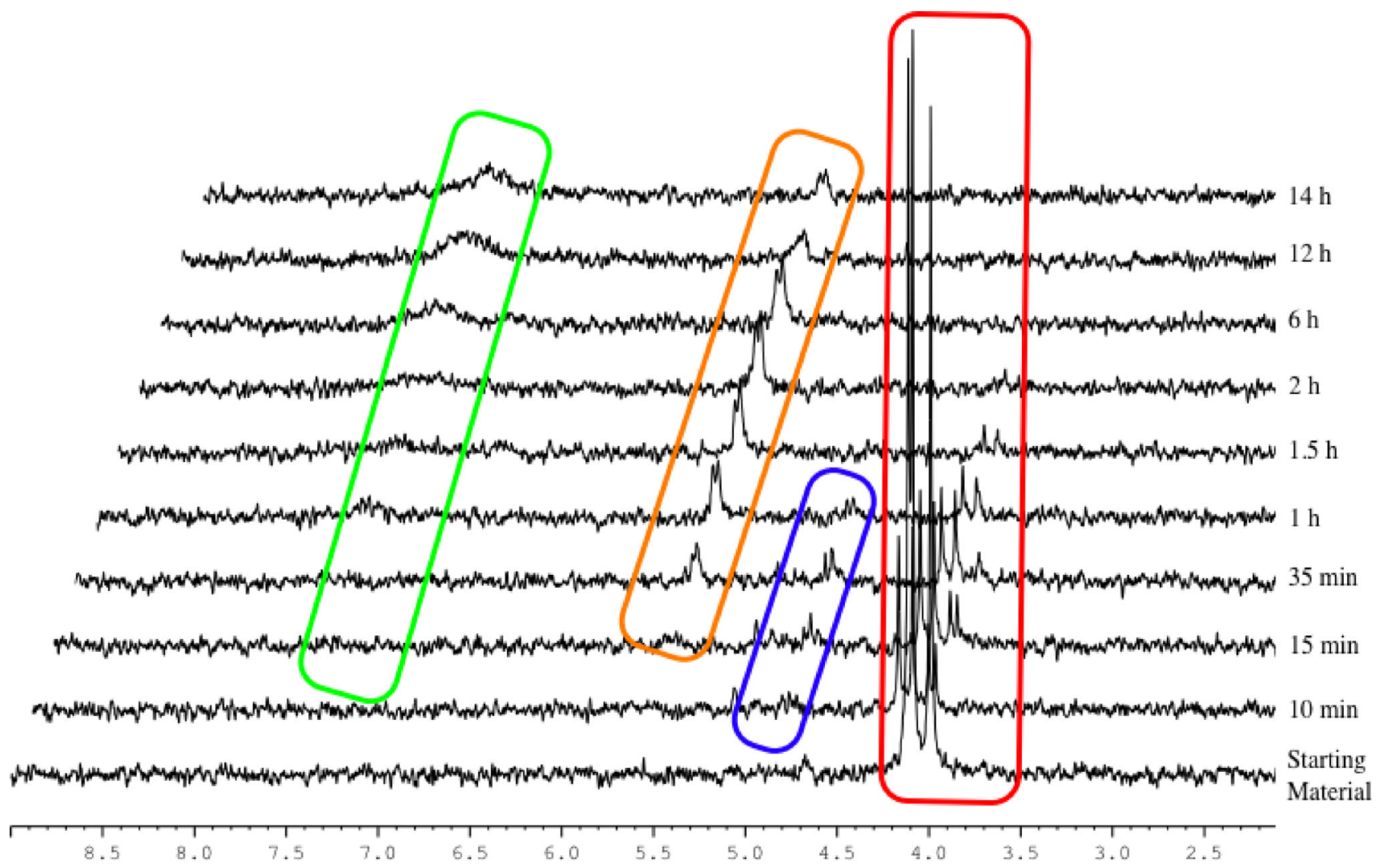

Figure 9.

Carboxypeptidase-mediated cleavage of compound $\mathbf{6 9}$, monitored by ${ }^{31} \mathrm{P}-\mathrm{NMR}$. 


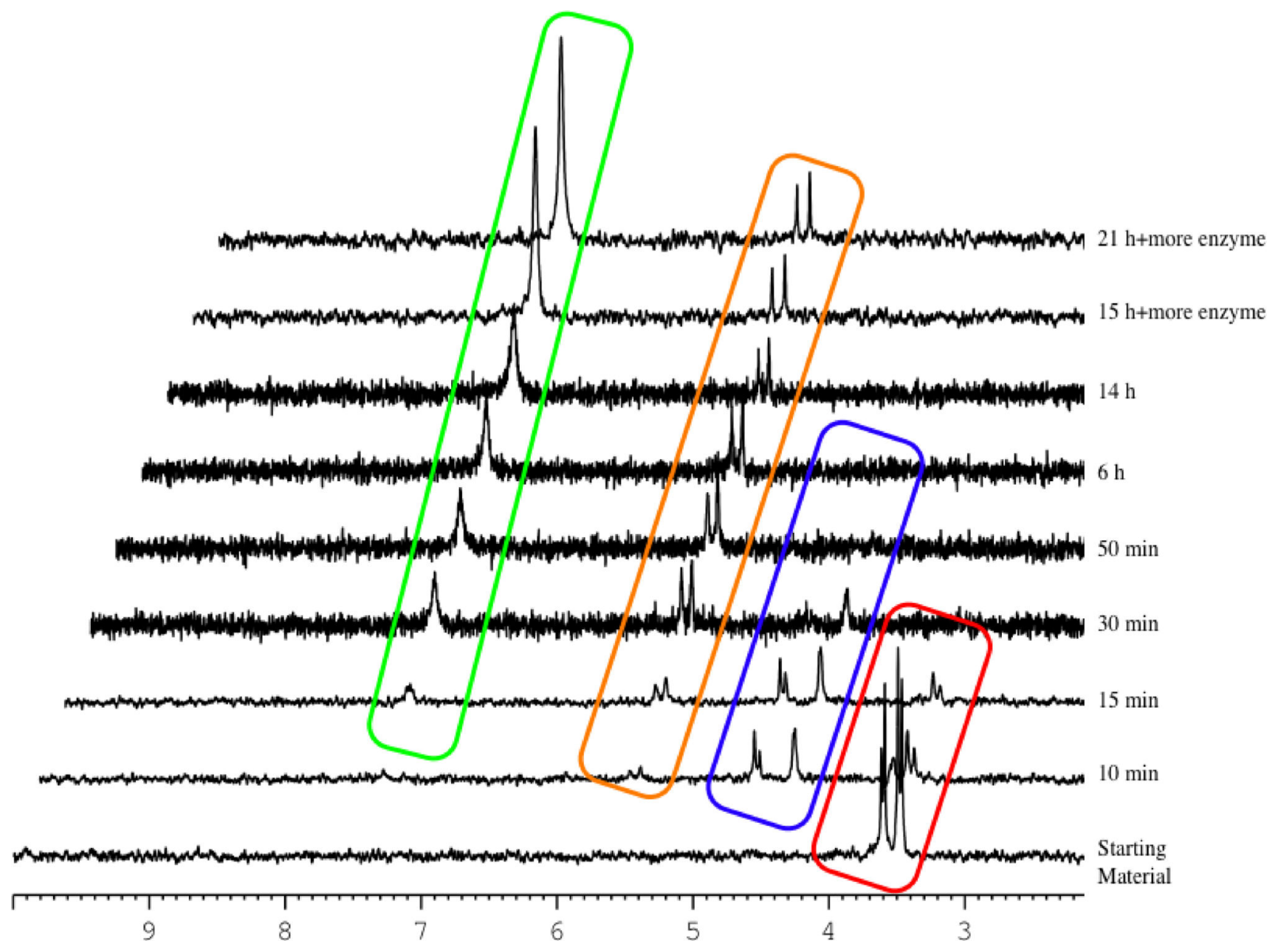

Figure 10.

Carboxypeptidase-mediated cleavage of compound $\mathbf{6 0}$, monitored by ${ }^{31} \mathrm{P}-\mathrm{NMR}$. 


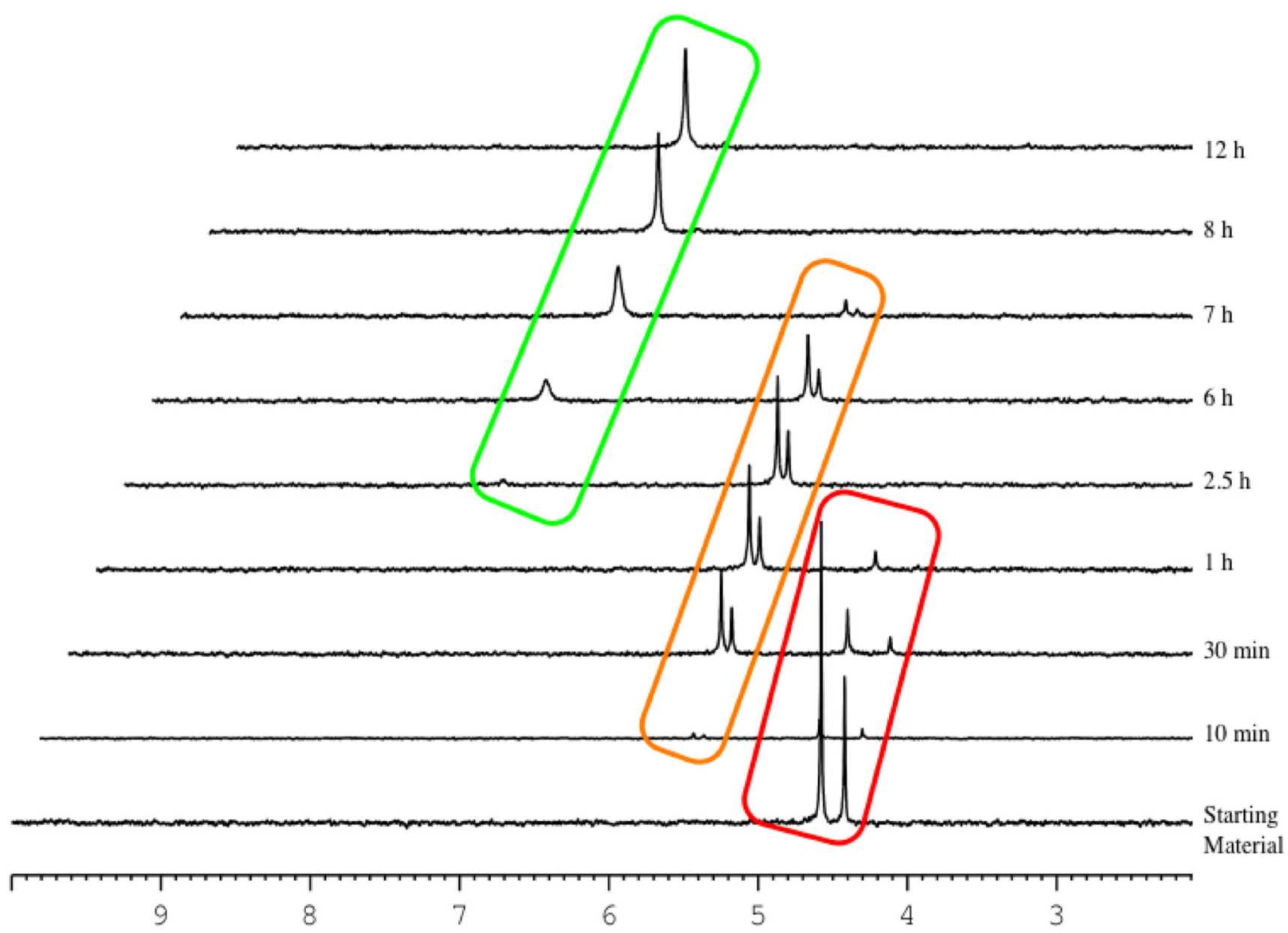

Figure 11.

Carboxypeptidase-mediated cleavage of compound $\mathbf{7 5}$, monitored by ${ }^{31} \mathrm{P}-\mathrm{NMR}$. 


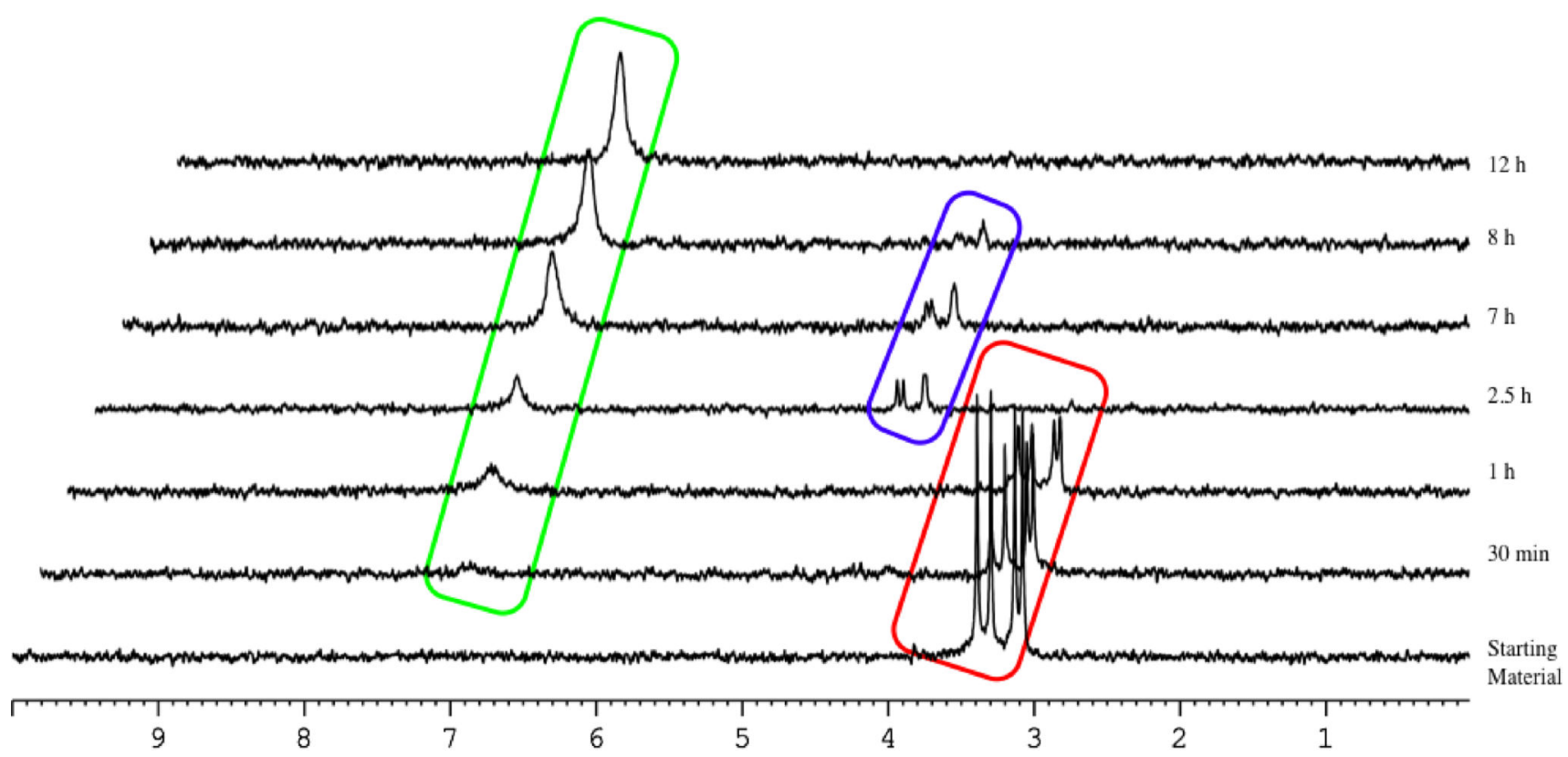

Figure 12.

Carboxypeptidase-mediated cleavage of compound 77, monitored by ${ }^{31} \mathrm{P}-\mathrm{NMR}$. 
<smiles>[R]OCC(CO[R])OCn1cnc2c(=O)[nH]c(/N=C/N(C)C)nc21</smiles>

8 and 16: $\mathrm{R}=$ NaphO-L-Ala-O ${ }^{\mathrm{i}} \mathrm{Pr} ; \mathrm{R}^{\prime}=\mathrm{H}$

9 and 17: $\mathrm{R}=\mathrm{R}^{\prime}=\mathrm{PhO}-\mathrm{L}-\mathrm{Ala}-\mathrm{OBn}$

10 and 18: $R=R^{\prime}=$ NaphO-L-Ala-OBn

11 and 19: $\mathrm{R}=\mathrm{R}^{\prime}=\mathrm{PhO}-\mathrm{DMG}-\mathrm{OBn}$

12 and 20: $\mathrm{R}=\mathrm{PhO}-\mathrm{DMG}-\mathrm{OBn} ; \mathrm{R}^{\prime}=\mathrm{H}$

13 and 21: $\mathrm{R}=\mathrm{R}^{\prime}=\mathrm{NaphO}-\mathrm{DMG}-\mathrm{OBn}$

14 and 22: $\mathrm{R}=\mathrm{NaphO}-\mathrm{DMG}-\mathrm{OBn} ; \mathrm{R}^{\prime}=\mathrm{H}$

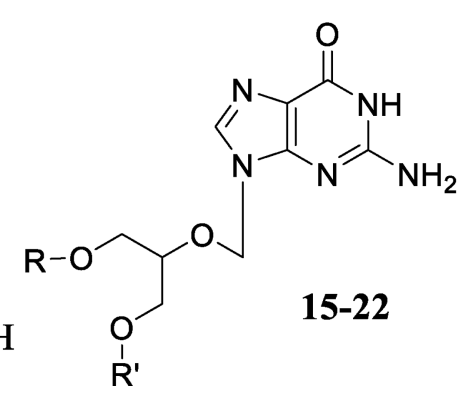

Scheme 1.

Reagents and conditions: ( 1 ) dimethylformamide dimethyl acetal, anhydrous DMF, rt, 1 day; (ii) appropriate phosphorochloridate, ${ }^{\mathrm{t}} \mathrm{BuMgCl}$, anhydrous $\mathrm{THF} / \mathrm{pyridine}, \mathrm{rt}, 24-84 \mathrm{~h}$; (iii) 2propanol, reflux, 24-80 h. 
<smiles>Cc1nc2c(ncn2COC(CO)CO)c(=O)[nH]1</smiles><smiles>[Y10]Nc1nc2c(ncn2CCOC(CO)CO)c(=O)[nH]1</smiles>

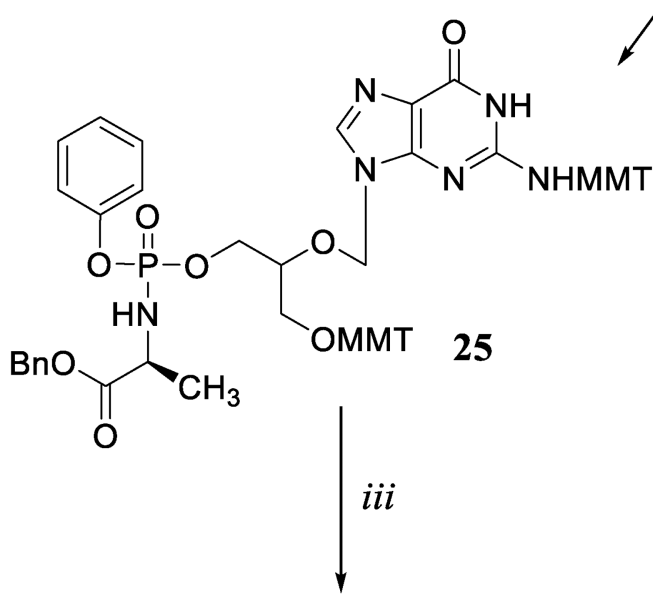
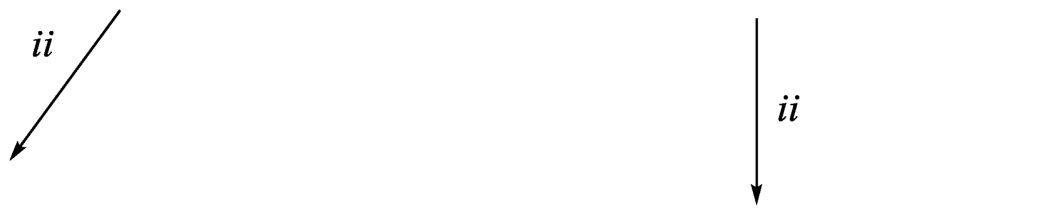<smiles>C[C@H](NP(=O)(OCC(CO)OCn1cnc2c(=O)[nH]c(N)nc21)Oc1ccccc1)C(=O)OCc1ccccc1</smiles><smiles>[Y17]Nc1nc2c(ncn2COC(CO)COP(=O)(N[C@@H](C)C(=O)OCc2ccccc2)Oc2cccc3ccccc23)c(=O)[nH]1</smiles>

Scheme 2.

Reagents and conditions: (i) MMT-Cl, TEA, DMAP, anhydrous DMF, rt, 2 h; (ii) appropriate phosphorochloridate, ${ }^{\mathrm{t}} \mathrm{BuMgCl}$, anhydrous THF, rt, overnight; (iii) DCM/ $\mathrm{MeOH}, \mathrm{PTSA}, \mathrm{rt}, 2 \mathrm{~h}$. 
<smiles>[R]O[R]OCC(CCn1cnc2c(=O)[nH]c(/N=C/N(C)C)nc21)CO[R]</smiles>

30 and 36: $\mathrm{R}=\mathrm{R}^{\prime}=\mathrm{PhO}-\mathrm{L}-\mathrm{Ala}-\mathrm{OBn}$ 31 and 37: $\mathrm{R}=\mathrm{R}^{\prime}=$ NaphO-L-Ala-OBn 32 and 38: $\mathrm{R}=\mathrm{R}^{\prime}=\mathrm{PhO}-\mathrm{DMG}-\mathrm{OBn}$ 33 and 39: $\mathrm{R}=\mathrm{PhO}-\mathrm{DMG}-\mathrm{OBn} ; \mathrm{R}^{\prime}=\mathrm{H}$ 34 and $40: \mathrm{R}=\mathrm{R}^{\prime}=\mathrm{NaphO}-\mathrm{DMG}-\mathrm{OBn}$ 35 and 41: $\mathrm{R}=$ NaphO-DMG-OBn; $\mathrm{R}^{\prime}=\mathrm{H}$<smiles>[R]OCC(CCn1cnc2c(=O)[nH]c(N)nc21)CO[R]</smiles>

Scheme 3.

Reagents and conditions: (i) dimethylformamide dimethyl acetal, anhydrous DMF, rt, 6 h; (ii) appropriate phosphorochloridate, ${ }^{\mathrm{t}} \mathrm{BuMgCl}$, anhydrous $\mathrm{THF} /$ pyridine, rt, 8-16 h; (iii) 2propanol, reflux, 24-72 h. 


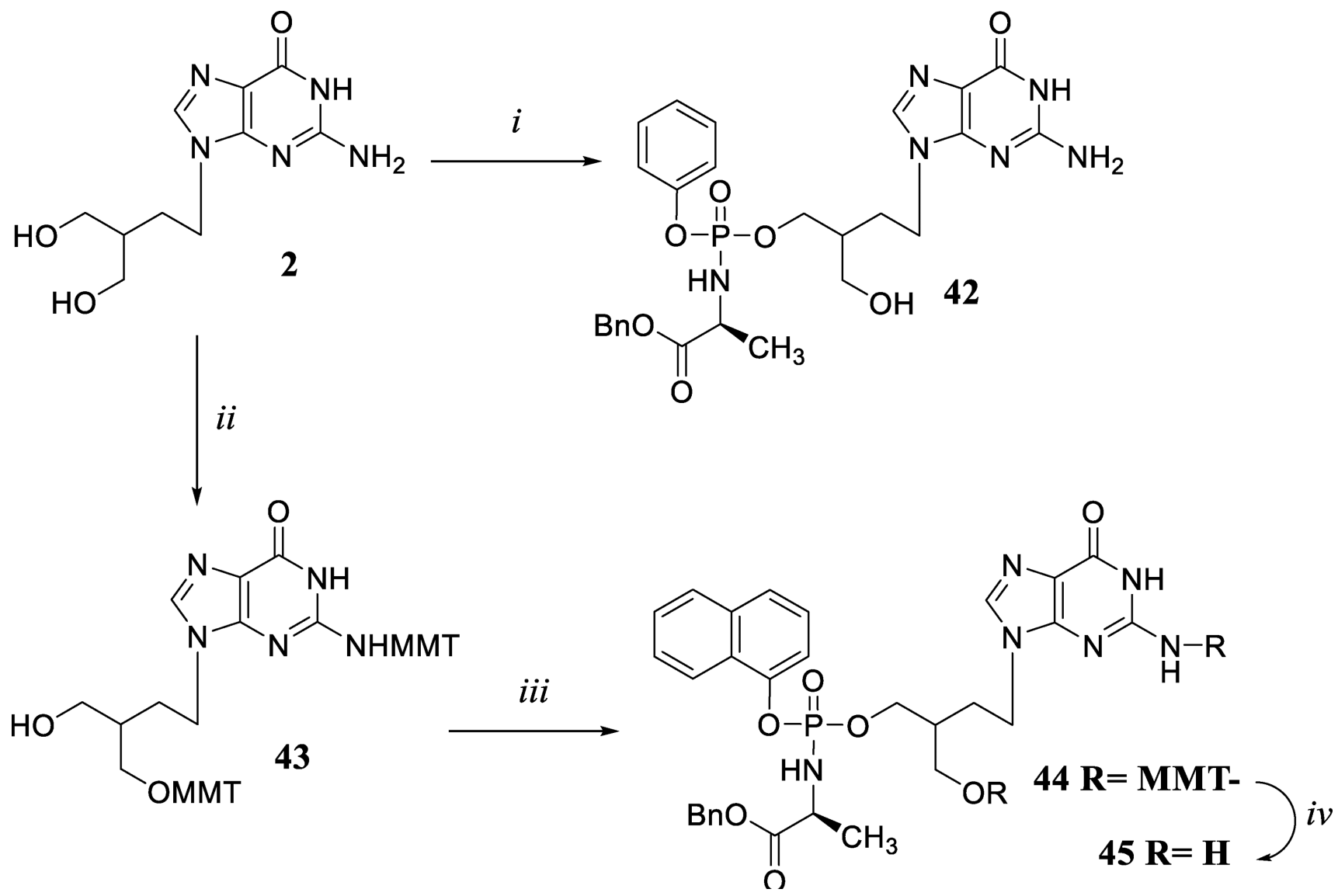

Scheme 4.

Reagents and conditions: (i) appropriate phosphorochloridate, ${ }^{\mathrm{t}} \mathrm{BuMgCl}$, anhydrous pyridine, rt overnight; (ii) MMT-Cl, TEA, DMAP, anhydrous DMF, rt, 2 h; (iii) appropriate phosphorochloridate, ${ }^{\mathrm{t}} \mathrm{BuMgCl}$, anhydrous THF, rt, overnight; (iv) DCM/MeOH, PTSA, rt, 2 h. 


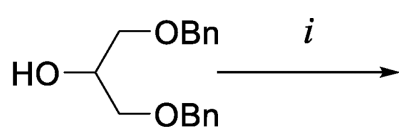

46

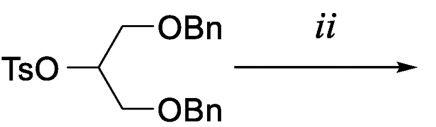

47

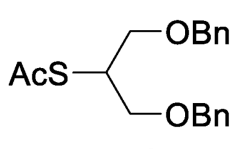

48

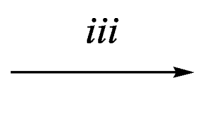

49

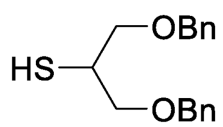

$i v, v, v i$<smiles>CC(=O)OCC(COC(C)(C)C)SCn1cnc2c(=O)[nH]c(NCC#CC(C)OCc3ccccc3)nc21</smiles>

Scheme 5.

Reagents and conditions: (i) para-toluene sulfonyl chloride, anhydrous pyridine, $\mathrm{rt}$ overnight; (ii) potassium thioacetate, anhydrous DMF, $90{ }^{\circ} \mathrm{C}, 2 \mathrm{~h}$; (iii) $\mathrm{MeOH} / \mathrm{NH}_{3}, \mathrm{rt}, 16 \mathrm{~h}$; or $\mathrm{MeONa}$, anhydrous $\mathrm{MeOH}, \mathrm{rt}, 1.5 \mathrm{~h}$; (iv) paraformaldehyde, $\mathrm{HCl}$ gas, anhydrous 1,2dichloroethane, $0{ }^{\circ} \mathrm{C}, 2 \mathrm{~h}$; (v) sodium acetate, anhydrous DMF, $\mathrm{rt}, 2 \mathrm{~h}$; (vi) diacetylguanine, bis(4-nitrophenyl)phosphate, sulfolane, $100^{\circ} \mathrm{C}, 6 \mathrm{~h}$ then $\mathrm{rt}, 17 \mathrm{~h}$; (vii) acetic anhydride, $\mathrm{BF}_{3} \mathrm{OEt}_{2}$, rt, $2.5 \mathrm{~h}$; (viii) $\mathrm{MeOH} / \mathrm{NH}_{3}$, rt, $18 \mathrm{~h}$. 


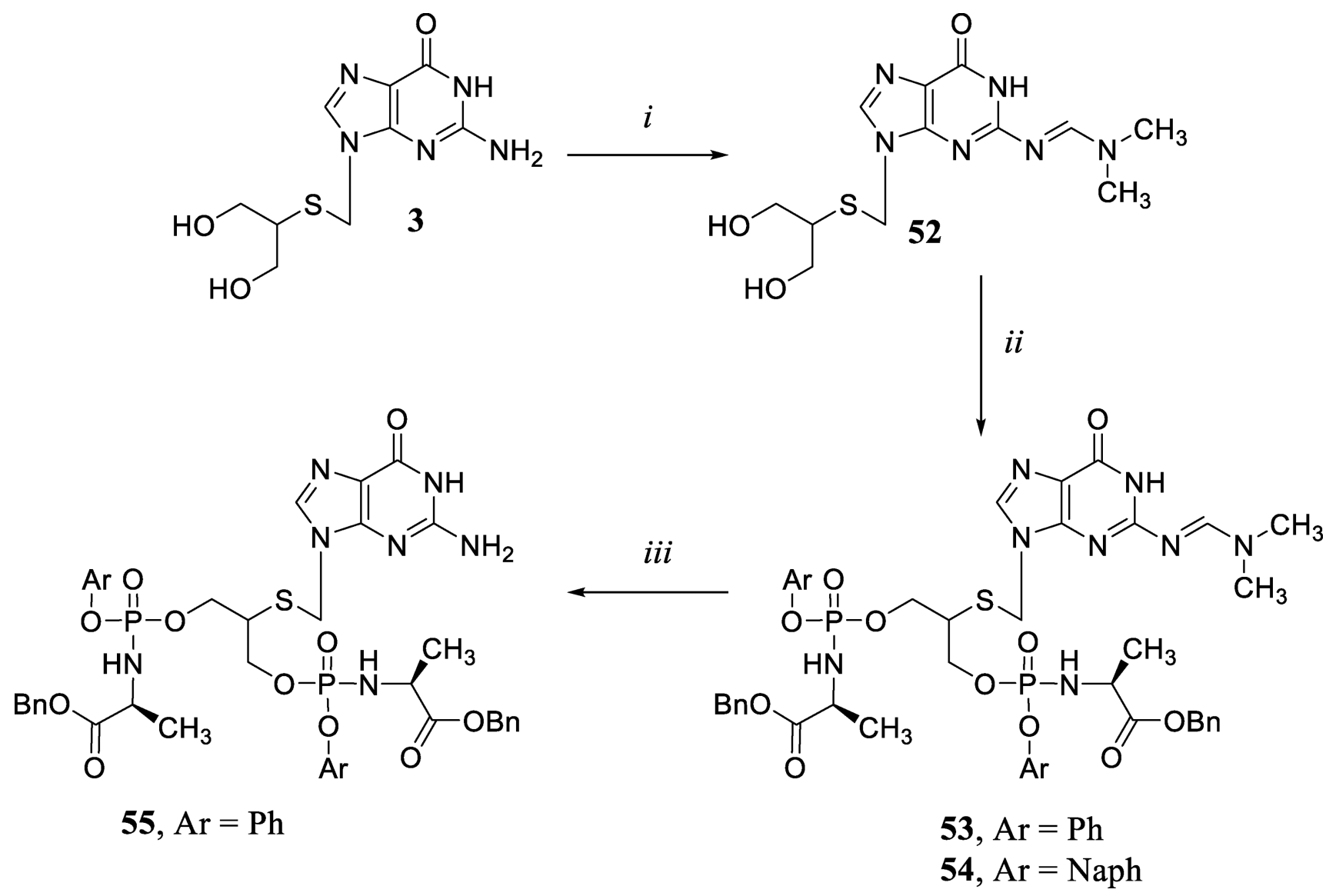

Scheme 6.

Reagents and conditions: (i) dimethylformamide dimethyl acetal, anhydrous DMF, rt, overnight; (ii) appropriate phosphorochloridate, ${ }^{\mathrm{t}} \mathrm{BuMgCl}$, anhydrous THF/pyridine, $\mathrm{rt}, 16 \mathrm{~h}$; (iii) 2-propanol, reflux, 24-72 h. 
<smiles>CC(=O)OCC(CCn1cnc2c(=O)[nH]c(N)nc21)CC(CCn1cnc2c(=O)[nH]c(N)nc21)COC(C)(C)C</smiles>

Scheme 7.

Reagents and conditions: (i) acetic anhydride, DMAP, anhydrous DMF, $45^{\circ} \mathrm{C}, 1.5 \mathrm{~h}$; (ii)

$\mathrm{POCl}_{3}$, benzyltriethylammonium chloride, $N, N$-dimethylaniline, anhydrous AcCN, $70{ }^{\circ} \mathrm{C}, 1$ h; (iii) $\mathrm{MeOH} / \mathrm{NH}_{3}$, rt, 6 h; (iv) MeONa, anhydrous $\mathrm{MeOH}, 40^{\circ} \mathrm{C}, 6 \mathrm{~h}$. 
<smiles>C[C@H](NP(=O)(OCC(COP(=O)(N[C@@H](C)C(=O)OCc1ccccc1)Oc1ccccc1)COP(=O)(N[C@@H](C)C(=O)OCC(CO)CCn1cnc2c(Cl)nc(N)nc21)Oc1ccccc1)Oc1ccccc1)C(=O)OCc1ccccc1</smiles>

Scheme 8.

Reagents and conditions: (i) PhO-L-Ala-OBn phosphorochloridate, ${ }^{\mathrm{t}} \mathrm{BuMgCl}$, anhydrous THF, rt, $24 \mathrm{~h}$. 


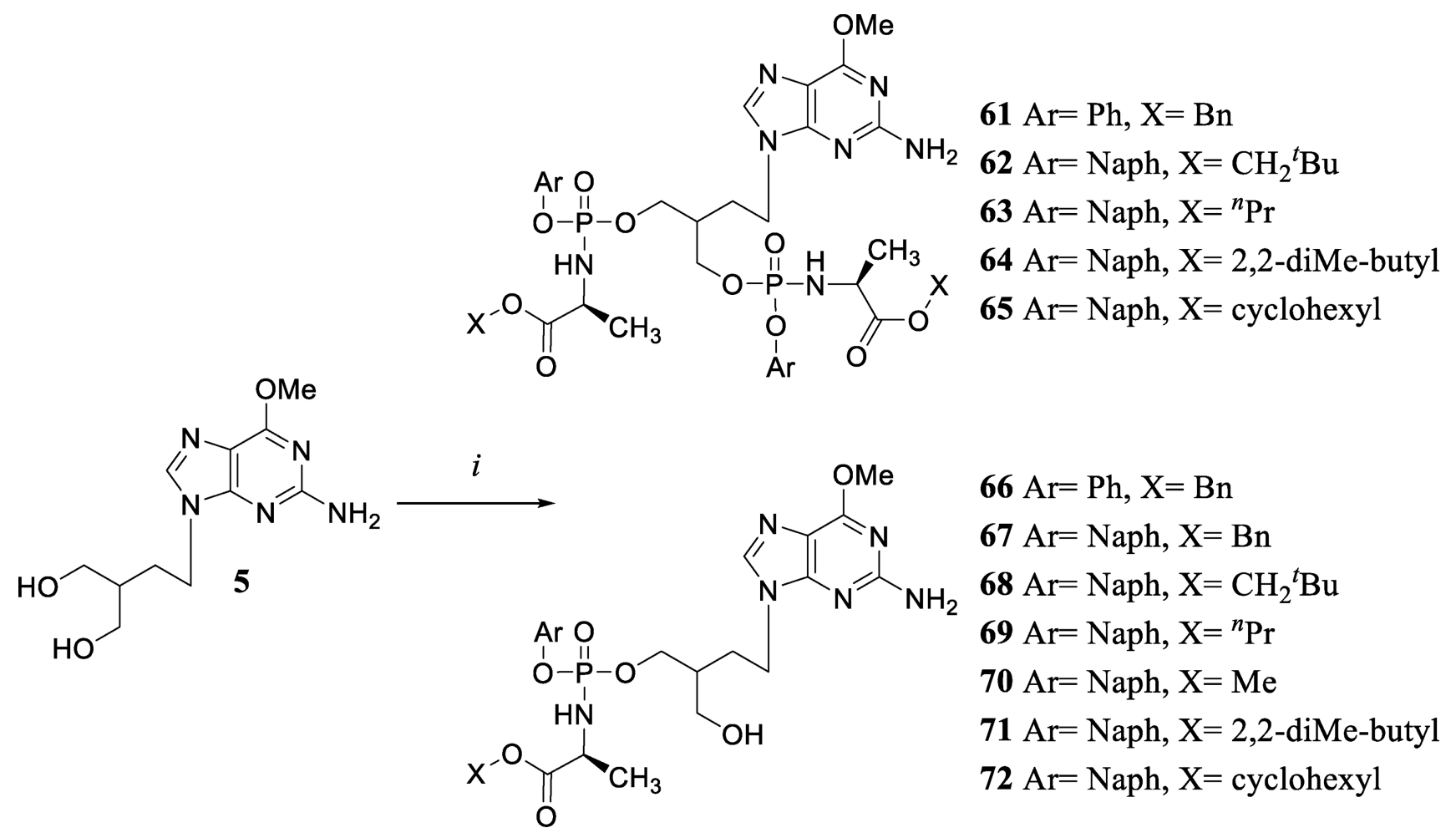

Scheme 9.

Reagents and conditions: (i) appropriate phosphorochloridate, ${ }^{\mathrm{t}} \mathrm{BuMgCl}$, anhydrous $\mathrm{THF}, \mathrm{rt}$, 40-48 h. 
<smiles>CCOC(=O)[C@H](C)NP1(=O)OCC(OCn2cnc3c(=O)[nH]c(/N=C/N(C)C)nc32)CO1</smiles>

Scheme 10.

Reagents and conditions: (i) Ethoxy-L-alaninyl dichlorophosphate, ${ }^{\mathrm{t}} \mathrm{BuMgCl}$, anhydrous THF/pyridine, rt, $40 \mathrm{~h}$; (ii) 2-propanol, reflux, $9 \mathrm{~h}$. 
<smiles>C[C@H](NP1(=O)OCC(OCn2cnc3c(Cl)nc(N)nc32)CO1)C(=O)OBr</smiles>

Scheme 11.

Reagents and conditions: (i) Benzoxy-L-alaninyl dichlorophosphate, ${ }^{t} \mathrm{BuMgCl}$, anhydrous THF, rt, $22 \mathrm{~h}$. 
<smiles>CC(=O)OCC(CCn1cnc2c(Cl)nc(N)nc21)CO[C@H](CO)CO[C@H](CO)COC(C)=O</smiles><smiles>CCCO[C@H](COP(=O)(N[C@@H](C)C(=O)Cc1ccccc1)Oc1ccccc1)OCn1cnc2c(Cl)nc(N)nc21</smiles>

Scheme 12.

Reagents and conditions: (i) $\mathrm{MeOH}, \mathrm{NH}_{3}$ gas generated in situ, $0{ }^{\circ} \mathrm{C}$, 5.5h; (ii) phenyl(benzoxy-L-alaninyl)-phosphochloridate, ${ }^{\mathrm{t}} \mathrm{BuMgCl}$, anhydrous THF, rt, $16 \mathrm{~h}$. 

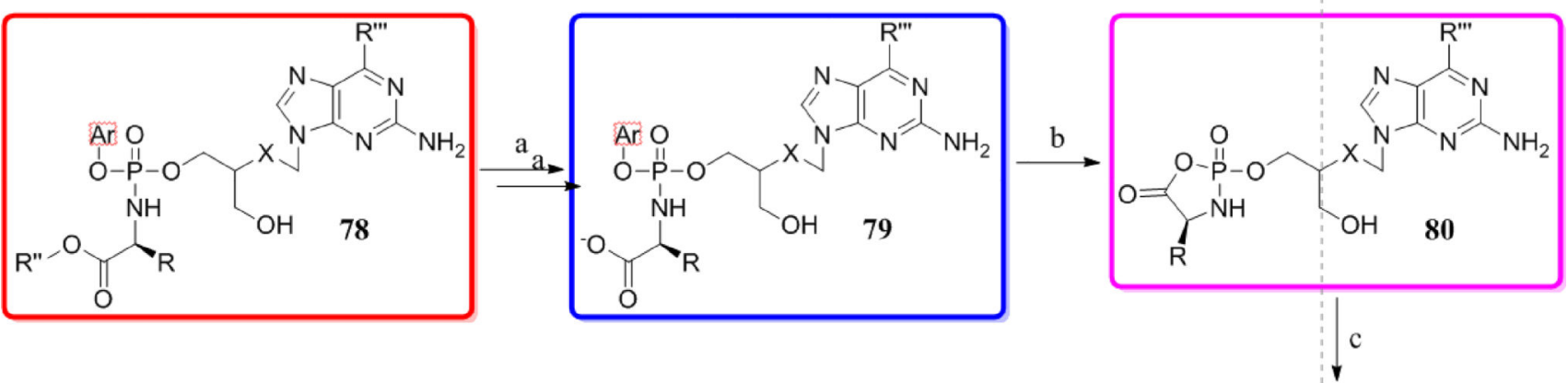

a: esterase or carboxypeptidase type enzyme;

b: spontaneous;

c: spontaneous;

d: phosphoramidase type enzyme.
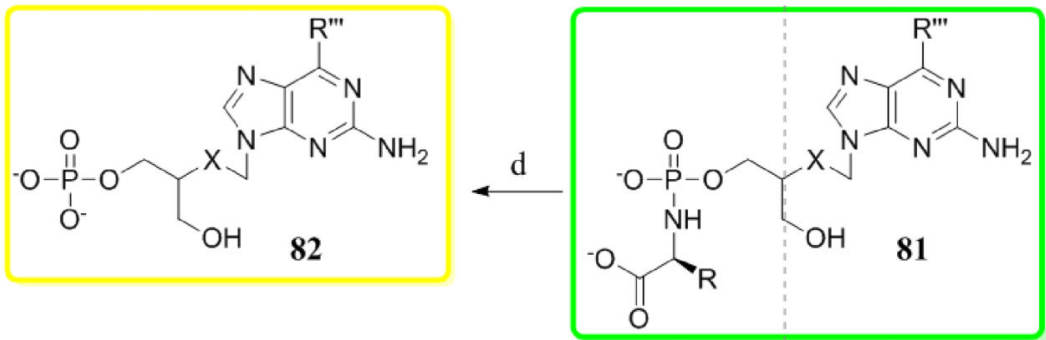

Scheme 13.

Putative mechanism of bioactivation of ProTides. 

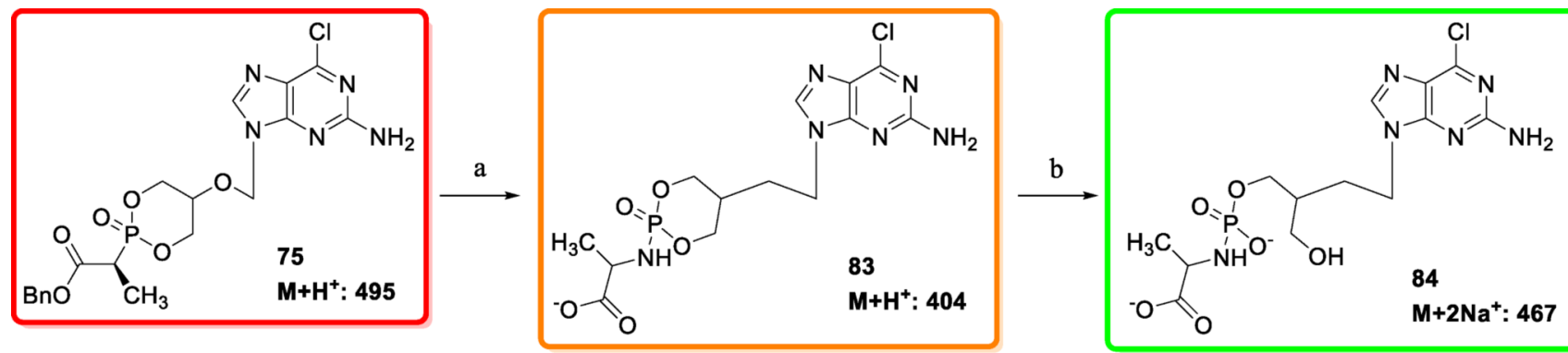

Scheme 14.

Putative mechanism of bioactivation for compound $\mathbf{7 5}$ 


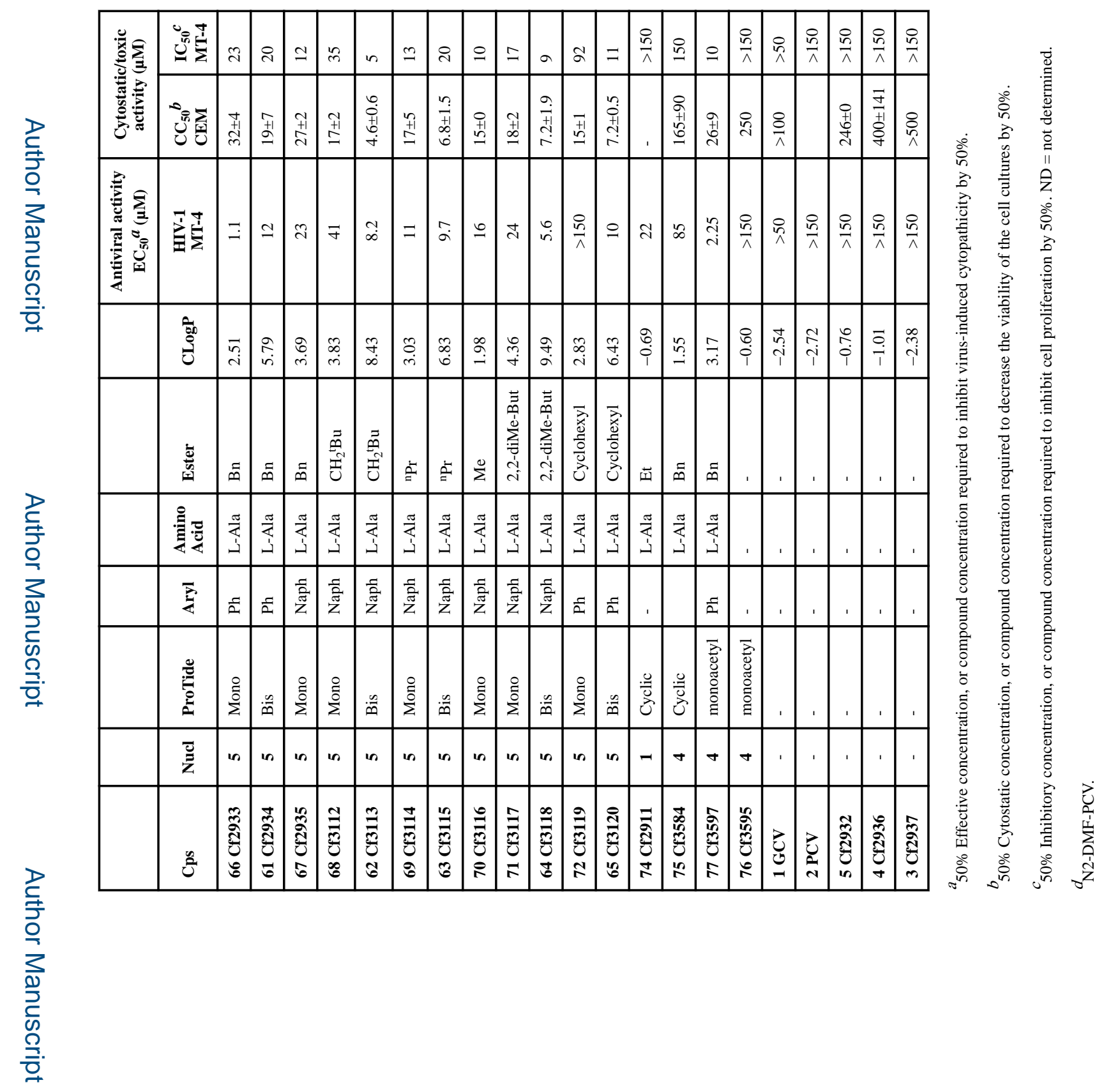

로을 


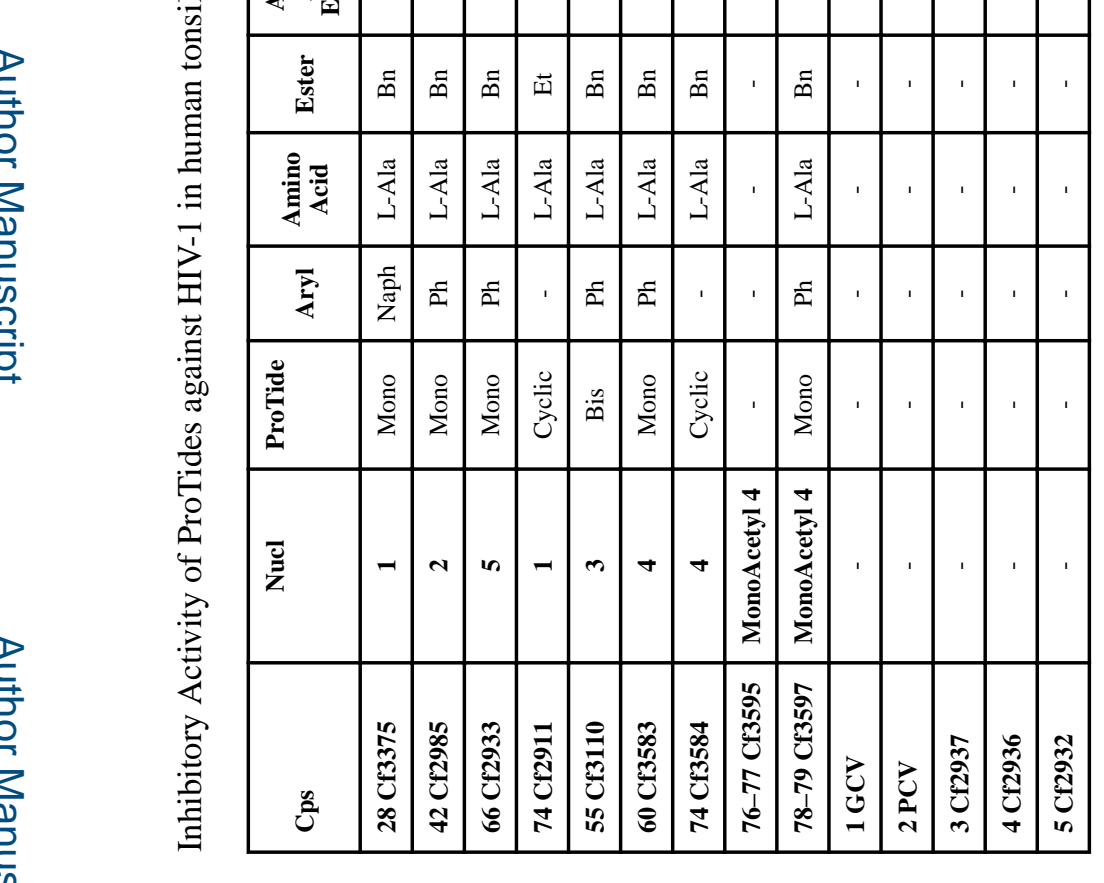




\begin{tabular}{|c|c|c|c|c|c|c|c|c|c|c|c|c|c|c|c|c|c|c|c|c|c|c|c|}
\hline 善号 & 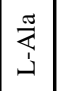 & 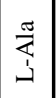 & 焉 & $\begin{array}{l}\frac{\pi}{4} \\
\end{array}$ & 爫 & 茫 & $\sum_{0}^{0}$ & $\sum_{\Delta}^{0}$ & $\sum_{0}^{0}$ & $\sum_{\Delta}^{0}$ & 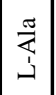 & $\stackrel{5}{4}$ & $\begin{array}{l}\frac{\pi}{4} \\
\end{array}$ & ذئ & 吾 & 胥 & $\sum_{0}^{0}$ & $\sum_{0}^{0}$ & $\sum_{0}^{0}$ & 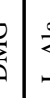 & 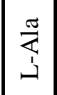 & 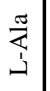 & $\stackrel{5}{4}$ \\
\hline$\frac{3}{4}$ & 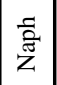 & 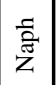 & $\bar{\Omega}$ & $\tilde{\Omega}$ & 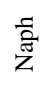 & 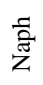 & $\approx$ & $\bar{a}$ & 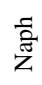 & $\begin{array}{l}\overline{\tilde{a}} \\
\text { zै }\end{array}$ & $\overrightarrow{2}$ & $\overline{2}$ & $\begin{array}{l}\overline{\tilde{z}} \\
\bar{z}\end{array}$ & $\begin{array}{l}\overline{\bar{a}} \\
\text { ב్ }\end{array}$ & $\overline{2}$ & 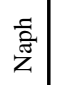 & $\underline{2}$ & $\stackrel{2}{2}$ & $\begin{array}{l}\text { 产 } \\
\text { za }\end{array}$ & 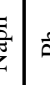 & $\vec{x}$ & 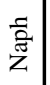 & 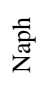 \\
\hline 总 & $\frac{m}{n}$ & 离 & $\frac{m}{n}$ & $\sum_{0}^{\circ}$ & $\stackrel{\frac{m}{m}}{\circ}$ & 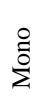 & $\begin{array}{l}0 \\
\vdots \\
\Sigma \\
\Sigma\end{array}$ & $\frac{2}{n}$ & $\frac{n}{n}$ & $\stackrel{\circ}{\sum_{\Sigma}^{\circ}}$ & $\frac{\infty}{\infty}$ & $\stackrel{\circ}{\stackrel{0}{\Sigma}}$ & $\stackrel{n}{n}$ & $\frac{2}{\infty}$ & $\frac{n}{n}$ & $\stackrel{\circ}{\sum^{\circ}}$ & $\frac{n}{n}$ & $\begin{array}{l}0 \\
\stackrel{0}{0}\end{array}$ & $\stackrel{\circ}{\circ}$ & 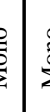 & $\because \frac{n}{\infty}$ & $\stackrel{0}{\stackrel{0}{\Delta}}$ & $\stackrel{\circ}{\sum_{\Sigma}^{\circ}}$ \\
\hline $\mid \overline{\bar{G}}$ & -1 & -1 & - & - & - & - & -7 & -7 & - & - & $\sim$ & $N$ & $N$ & $N$ & $N$ & $N$ & $N$ & $N$ & $N$ & $\begin{array}{llll} & 4\end{array}$ & in & in & in \\
\hline uे & 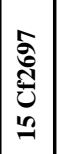 & 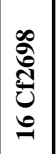 & 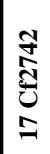 & 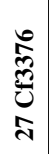 & 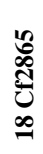 & 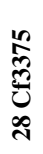 & 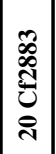 & 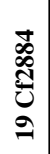 & 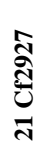 & 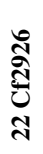 & 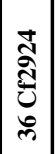 & 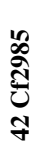 & 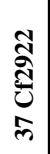 & 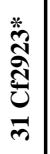 & 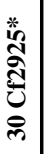 & 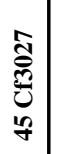 & 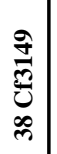 & 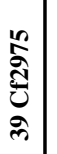 & 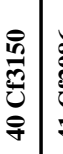 & 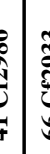 & 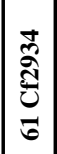 & 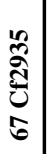 & 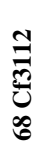 \\
\hline
\end{tabular}


로을

\begin{tabular}{|c|c|c|c|c|c|c|c|c|c|c|c|c|c|c|c|c|c|c|c|c|c|}
\hline 总 & $\frac{Z}{2}$ & 通 & 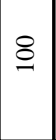 & 齐 & $\begin{array}{l}8 \\
\text { 条 }\end{array}$ & 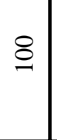 & 齐 & 通 & $\frac{8}{\wedge}$ & $\frac{8}{\wedge}$ & $\stackrel{8}{\wedge}$ & 文 & 穴 & 会 & $\frac{8}{\wedge}$ & ્ָતે & $\frac{8}{\wedge}$ & $\frac{8}{\wedge}$ & $\frac{8}{\wedge}$ & $\stackrel{8}{\wedge}$ & $\frac{8}{\wedge}$ \\
\hline \multirow{3}{*}{ 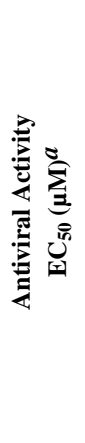 } & $\begin{array}{l}1 \\
0 \\
0 \\
0\end{array}$ & $\frac{8}{\wedge}$ & त्रे & $\frac{8}{\wedge}$ & $\frac{8}{\wedge}$ & त्रि & $\stackrel{8}{\wedge}$ & $\mid \begin{array}{l}\infty \\
\sim \\
+1 \\
q \\
q\end{array}$ & $\frac{8}{\wedge}$ & $\frac{8}{\wedge}$ & $\stackrel{8}{\wedge}$ & $\frac{8}{\wedge}$ & $\frac{8}{\wedge}$ & 立 & $\frac{8}{\wedge}$ & $\begin{array}{l}0 \\
\infty \\
+1 \\
0 \\
0\end{array}$ & $\begin{array}{l}\vec{t} \\
\dot{+} \\
+1 \\
\tilde{+} \\
\dot{+}\end{array}$ & $\stackrel{\circ}{+}$ & 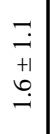 & $\stackrel{8}{\wedge}$ & $\stackrel{8}{\circ}$ \\
\hline & 常 & $\frac{8}{\lambda}$ & $\begin{array}{l}\infty \\
+1 \\
n \\
n\end{array}$ & $\frac{8}{\wedge}$ & $\frac{8}{\wedge}$ & $\begin{array}{l}\overrightarrow{1} \\
\stackrel{+1}{=}\end{array}$ & $\frac{8}{\wedge}$ & $\begin{array}{l}0 \\
+1 \\
0 \\
0\end{array}$ & $\frac{8}{\wedge}$ & $\frac{8}{\wedge}$ & $\frac{8}{\wedge}$ & $\frac{8}{\wedge}$ & $\frac{8}{\wedge}$ & 至 & $\frac{8}{\wedge}$ & $\begin{array}{l}m \\
\vdots \\
+1 \\
+ \\
0\end{array}$ & $\begin{array}{l}0 \\
0 \\
0 \\
+1 \\
0 \\
0 \\
0\end{array}$ & $\begin{array}{l}m \\
0 \\
+1 \\
0 \\
0 \\
0\end{array}$ & $\begin{array}{l}-1 \\
0 \\
+1 \\
n \\
0\end{array}$ & $\frac{8}{\wedge}$ & $\frac{8}{\wedge}$ \\
\hline & 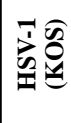 & $\frac{8}{\wedge}$ & $\begin{array}{l}+1 \\
+1 \\
\pm\end{array}$ & $\frac{\otimes}{\wedge}$ & $\frac{8}{\wedge}$ & $\begin{array}{l}1 \\
+1 \\
=\end{array}$ & $\frac{8}{\wedge}$ & $\mid \begin{array}{l}0 \\
+1 \\
+1 \\
-\end{array}$ & $\stackrel{8}{\wedge}$ & $\frac{8}{\wedge}$ & $\frac{\AA}{\wedge}$ & $\stackrel{\otimes}{\wedge}$ & $\frac{8}{\wedge}$ & 至 & $\frac{8}{\wedge}$ & $\begin{array}{l}n \\
0 \\
+1 \\
+1 \\
0\end{array}$ & $\begin{array}{l}\tilde{0} \\
0 \\
+1 \\
\ddot{0} \\
0 \\
0\end{array}$ & $\begin{array}{l}3 \\
0 \\
+1 \\
n \\
0\end{array}$ & $\begin{array}{l}-1 \\
0 \\
+1 \\
+ \\
0\end{array}$ & $\stackrel{\otimes}{\wedge}$ & $\frac{8}{\wedge}$ \\
\hline & 离 & 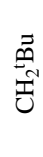 & $\cong$ & $\stackrel{\Xi}{\Xi}$ & $\stackrel{\pi}{\Sigma}^{0}$ & 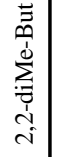 & 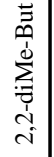 & 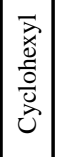 & 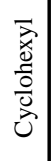 & $\bar{m}$ & $\frac{8}{\wedge}$ & ตี & $\tilde{\text { ๓ }}$ & 甶 & ตี & & & & & & \\
\hline & 产苞 & $\stackrel{\frac{\pi}{4}}{\lrcorner}$ & 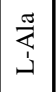 & 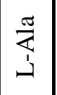 & \begin{tabular}{|l|} 
\\
\\
\end{tabular} & 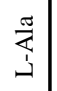 & 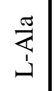 & 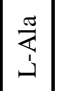 & 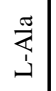 & \begin{tabular}{l}
3 \\
\multirow{4}{4}{} \\
\end{tabular} & 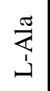 & 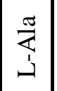 & 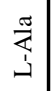 & 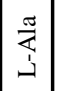 & $\begin{array}{l}\stackrel{g}{4} \\
\dot{4}\end{array}$ & & & & & & \\
\hline & 妾 & 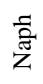 & $\mid$\begin{tabular}{l|} 
言 \\
吾
\end{tabular} & $\mid \begin{array}{l}\overline{0} \\
\overline{\vec{a}} \\
\bar{z}\end{array}$ & $\mid \begin{array}{l}\bar{a} \\
\overline{\mathrm{d}} \\
\mathrm{z}\end{array}$ & $\mid \begin{array}{l}\vec{a} \\
\vec{a} \\
\text { ż }\end{array}$ & $\mid \begin{array}{l}\vec{a} \\
\bar{a} \\
z\end{array}$ & $\overrightarrow{2}$ & $\overline{2}$ & $\overrightarrow{2}$ & $\bar{\alpha}$ & $\tilde{2}$ & $\begin{array}{l}\overrightarrow{\widetilde{a}} \\
\overrightarrow{\widetilde{z}}\end{array}$ & & & & & & & & \\
\hline & 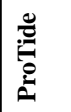 & $\frac{n}{0.0}$ & 总 & $\frac{m}{\infty}$ & 节 & 竞 & $\because \frac{\infty}{\infty}$ & 总 & $\stackrel{n}{m}$ & $\stackrel{20}{m}$ & $\stackrel{0}{0}$ & $\frac{m}{n}$ & $\frac{n}{m}$ & 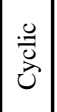 & $\begin{array}{l}\frac{9}{0} \\
\bar{u} \\
u\end{array}$ & & & & & & \\
\hline & \begin{tabular}{|l}
$\overline{\mathscr{V}}$ \\
$\bar{z}$
\end{tabular} & in & in & in & 10 & in & in & in & in & $\nabla$ & $\nabla$ & $\infty$ & $m$ & - & + & & . & 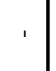 & , & & ' \\
\hline & $\hat{\tilde{u}}$ & 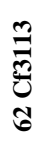 & 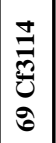 & 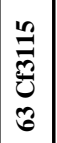 & 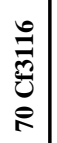 & 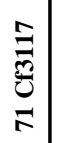 & 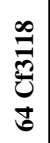 & 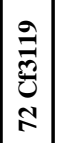 & 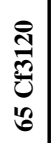 & $\begin{array}{l}\tilde{D} \\
0 \\
0 \\
0 \\
0 \\
0 \\
\text { in }\end{array}$ & $\begin{array}{l}0 \\
0 \\
0 \\
0 \\
0 \\
8 \\
8\end{array}$ & \begin{tabular}{|c|}
0 \\
$\bar{n}$ \\
0 \\
$i n$ \\
$i n$
\end{tabular} & 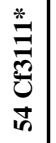 & 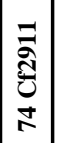 & 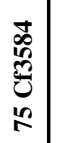 & & | & 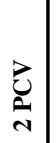 & 㒕 & 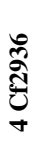 & 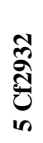 \\
\hline
\end{tabular}

로을 


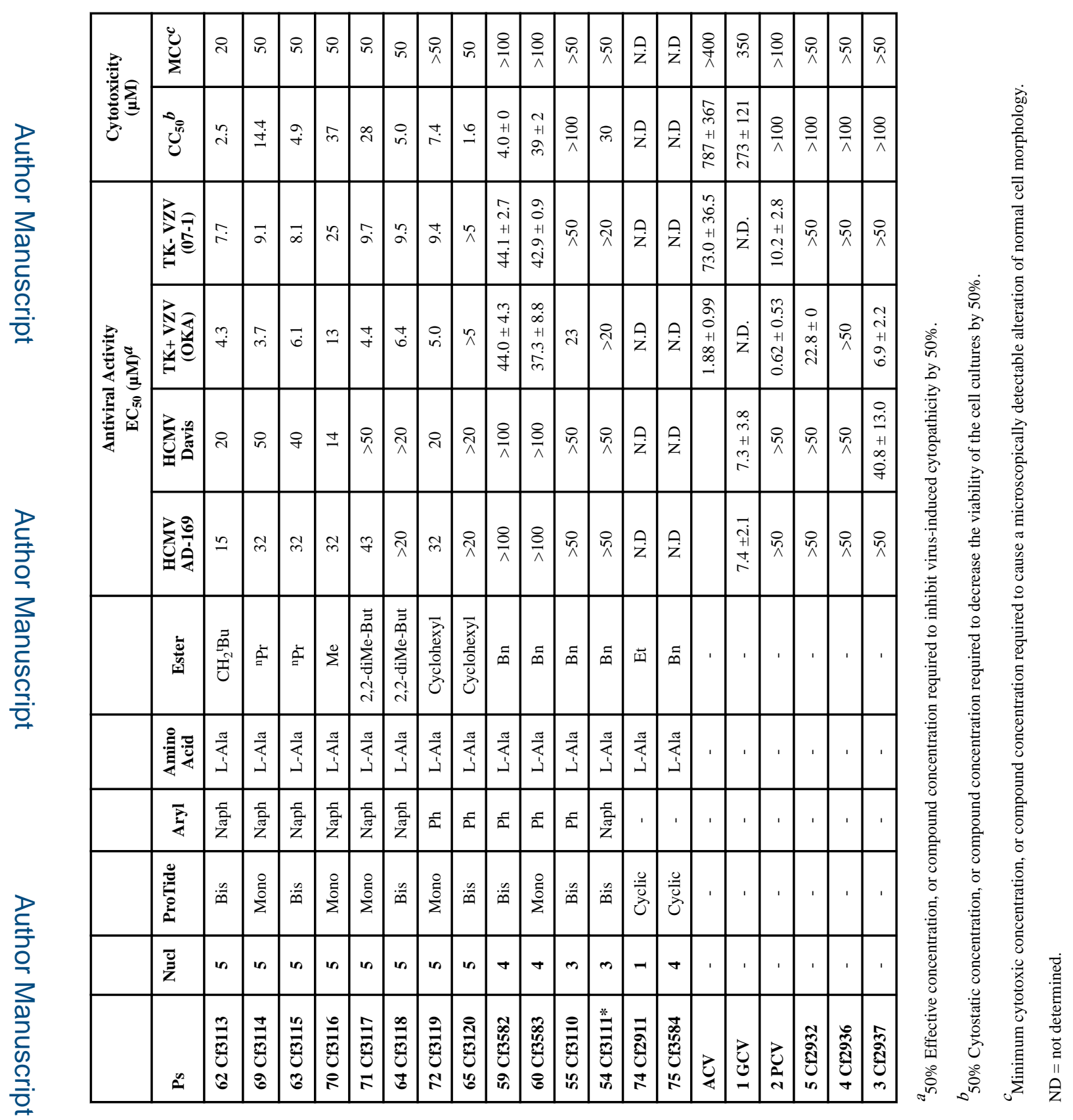

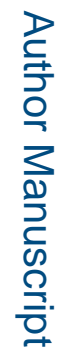

